\title{
Medial Habenula Output Circuit Mediated by $\alpha 5$ Nicotinic Receptor-Expressing GABAergic Neurons in the Interpeduncular Nucleus
}

\author{
Yun-Wei A. Hsu, ${ }^{1}$ Lynne Tempest, ${ }^{1}$ Lely A. Quina, ${ }^{1}$ Aguan D. Wei, ${ }^{1,4}$ Hongkui Zeng,,${ }^{5}$ and Eric E. Turner ${ }^{1,2,3}$ \\ ${ }^{1}$ Center for Integrative Brain Research, Seattle Children's Research Institute, and ${ }^{2}$ Department of Psychiatry and Behavioral Sciences, University of \\ Washington, Seattle, Washington 98101, ${ }^{3}$ Center on Human Development and Disability and ${ }^{4}$ Department of Neurological Surgery, University of \\ Washington, Seattle, Washington 98195, and ${ }^{5}$ Allen Institute for Brain Science, Seattle, Washington 98103
}

The Chrna5 gene encodes the $\alpha 5$ nicotinic acetylcholine receptor subunit, an "accessory" subunit of pentameric nicotinic receptors, that has been shown to play a role in nicotine-related behaviors in rodents and is genetically linked to smoking behavior in humans. Here we have used a BAC transgenic mouse line, $\alpha 5^{\mathrm{GFP}}$, to examine the cellular phenotype, connectivity, and function of $\alpha 5$-expressing neurons. Although the medial habenula (MHb) has been proposed as a site of $\alpha 5$ function, $\alpha 5^{\mathrm{GFP}}$ is not detectable in the MHb, and $\alpha 5 \mathrm{mRNA}$ is expressed there only at very low levels. However, $\alpha 5^{\mathrm{GFP}}$ is strongly expressed in a subset of neurons in the interpeduncular nucleus (IP), median raphe/paramedian raphe (MnR/PMnR), and dorsal tegmental area (DTg). Double-label fluorescence in situ hybridization reveals that these neurons are exclusively GABAergic. Transgenic and conventional tract tracing show that $\alpha 5^{\mathrm{GFP}}$ neurons in the IP project principally to the MnR/PMnR and DTg/interfascicular dorsal raphe, both areas rich in serotonergic neurons. The $\alpha 5^{\mathrm{GFP}}$ neurons in the IP are located in a region that receives cholinergic fiber inputs from the ventral $\mathrm{MHb}$, and optogenetically assisted circuit mapping demonstrates a monosynaptic connection between these cholinergic neurons and $\alpha 5^{\mathrm{GFP}}$ IP neurons. Selective inhibitors of both $\alpha 4 \beta 2$ - and $\alpha 3 \beta 4$-containing nicotinic receptors were able to reduce nicotine-evoked inward currents in $\alpha 5^{\mathrm{GFP}}$ neurons in the IP, suggesting a mixed nicotinic receptor profile in these cells. Together, these findings show that the $\alpha 5$-GABAergic interneurons form a link from the MHb to serotonergic brain centers, which is likely to mediate some of the behavioral effects of nicotine.

\section{Introduction}

Among behavioral health disorders, nicotine addiction is one of the largest global causes of morbidity and mortality (World Health Organization, 2008). Twin studies have estimated that the heritability of smoking is $50-75 \%$ (Hall et al., 2002), but the genetic basis of this complex disorder is elusive. Recent genomewide association studies have identified a risk haplotype for nicotine addiction in European populations encompassing the three clustered nicotinic acetylcholine receptor (nAChR) genes CHRNA3, CHRNA5, and CHRNB4 (Berrettini and Doyle, 2012), which encode the $\alpha 3, \alpha 5$, and $\beta 4 \mathrm{nAChR}$ subunits, respectively. The most common haplotype identified in these studies includes

Received July 3, 2013; revised Sept. 18, 2013; accepted Oct. 8, 2013.

Author contributions:Y.-W.A.H., H.Z., and E.E.T. designed research;Y.-W.A.H., L.T., L.A.Q., and A.D.W. performed research; H.Z. contributed unpublished reagents/analytic tools; Y.-W.A.H., L.A.Q., A.D.W., H.Z., and E.E.T. analyzed data; Y.-W.A.H., A.D.W., and E.E.T. wrote the paper.

This work was supported by National Institutes of Health (NIH) Grants R21 MH090478 and R01 MH093667 (E.E.T.) and by the National Institute of Mental Health under NIH Grant F32MH098498 (Y.-W.A.H.). The content is solely the responsibility of the authors and does not necessarily represent the official views of the NIH. E.E.T. is a National Alliance for Research on Schizophrenia and Depression Investigator. We thank Drs. Michael Marks, Sharon Grady, Petra Scholze, Arik Hone, Nurulain Zaveri, and J. Michael McIntosh for helpful discussions on nicotinic receptors and pharmacology. We also thank Silke Frahm-Barske for supplying a $\beta 4$ mRNA probe.

The authors declare no competing financial interests.

Correspondence should be addressed to Eric E. Turner, Seattle Children's Research Institute, 1900 Ninth Avenue, Mail Stop C9S-10, Seattle, WA 98101. E-mail: eric.turner@seattlechildrens.org.

DOI:10.1523/JNEUROSCI.2927-13.2013

Copyright $\odot 2013$ the authors $\quad 0270-6474 / 13 / 3318022-14 \$ 15.00 / 0$ a nonsynonymous single-nucleotide polymorphism in the CHRNA5 gene, D398N, which may affect receptor function (Kuryatov et al., 2011). Consistent with a role for the $\alpha 5$ subunit in nicotine addiction, mice with null mutations of the Chnra5 gene exhibit altered behavioral responses to nicotine, including resistance to nicotine-induced seizures, reduced withdrawal after chronic administration, and increased self-administration at high doses (Salas et al., 2003, 2009; Fowler et al., 2011). Thus, the sites of expression and function of the $\alpha 5$ subunit in the brain will help to define neural pathways governing nicotine-mediated behaviors.

Chrna3 and Chrnb4 are transcribed on the same chromosomal strand, are frequently coexpressed, and together form a pentameric receptor with pharmacology that is distinctive from the more widely expressed receptors containing $\alpha 4$ and $\beta 2$ subunits (Quick et al., 1999). The expression of $\alpha 3$ and $\beta 4$ is limited to a few areas of the CNS, with the highest levels of mRNA observed in the medial habenula (MHb; Marks et al., 1992). Chrna5 is transcribed on the opposite strand of the gene cluster, and $\alpha 5$ mRNA is expressed at high levels in the principal target of $\mathrm{MHb}$ efferents, the interpeduncular nucleus (IP). The $\alpha 5$ subunit is an "accessory" subunit that forms functional receptor channels only in combination with other $\alpha$ - and $\beta$-subunits, including $\alpha 4 \beta 2$ (Ramirez-Latorre et al., 1996), $\alpha 3 \beta 4$, and $\alpha 3 \beta 3$ (Wang et al., 1996).

Here we have used a BAC transgenic line, $\alpha 5^{\mathrm{GFP}}$, to reveal the anatomical and functional properties of $\alpha 5$ neurons in the habe- 
nula-interpeduncular-raphe pathway. Expression of $\alpha 5^{\mathrm{GFP}}$ is undetectable in the $\mathrm{MHb}$, and endogenous $\alpha 5$ mRNA is also expressed at very low levels there, but both are robustly expressed in the IP. The $\alpha 5$-expressing neurons in the IP are exclusively GABAergic, and they project primarily to the median raphe $(\mathrm{MnR})$, paramedian raphe $(\mathrm{PMnR})$, and dorsal tegmental area (DTg), where they terminate near 5-HT neurons in the caudal dorsal raphe (DRC) and interfascicular dorsal raphe (DRI). The $\alpha 5$-expressing IP neurons receive direct synaptic input from cholinergic neurons of the ventral $\mathrm{MHb}(\mathrm{vMHb})$ and exhibit nicotinic pharmacology consistent with $\alpha 5$ incorporation into both postsynaptic IP $\alpha 4 \beta 2$ and $\alpha 3 \beta 4$ receptors. Although two recent studies have proposed that $\alpha 5$ mediates behavioral effects via expression in the MHb (Fowler et al., 2011; Frahm et al., 2011), our results do not support a major role for $\alpha 5$ in the MHb in mice. Instead, they suggest that the physiological effects of $\alpha 5$ in the MHb pathway are mediated through GABAergic interneurons in the IP and raphe.

\section{Materials and Methods}

Animals. The $\alpha 5^{\mathrm{GFP}}$ BAC transgenic line Tg(Chrna5-EGFP)IG16Gsat/ Mmucd was generated by the GENSAT Project and obtained as cryogenically preserved sperm from the Mutant Mouse Regional Resource Center at the University of California, Davis. Recovery of live animals by in vitro fertilization of oocytes from C57BL/6 NCrl (Charles River) mice was performed by the University of Washington Transgenic Resources Program. This BAC transgene interrupts the $\alpha 5$ nicotinic receptor transcription unit and produces a cytoplasmic GFP; it does not express mRNA encoding $\alpha 5$ nicotinic receptors, and it does not disrupt the native genomic Chrna5 gene. The mouse line B6;129S6-Chat ${ }^{\text {tm1(cre)Lowl }}$ (Chat ${ }^{\mathrm{Cre}}$ ), expressing Cre recombinase from an internal ribosome entry site in the Chat gene $3^{\prime}$-untranslated region (3'-UTR), was obtained from the The Jackson Laboratory. The optogenetic lines Ai27, conditionally expressing a ChR2(H134R)-tdTomato fusion protein, and Ai32, conditionally expressing a ChR2-EYFP fusion protein, have been described previously (Madisen et al., 2012). The Cre-driver and optogenetic effector transgenic lines were backcrossed to C57BL/6NCrl, maintained separately on this genetic background, and interbred to produce F1 experimental animals.

Genotyping of transgenic mice was performed using real-time PCR with the following forward $(\mathrm{F})$ and reverse $(\mathrm{R})$ primer pairs: GENSAT $\alpha 5^{\text {GFP }}$ BAC transgene, F: ATCACTCTCGGCATGGACGA, R: TAGAAG GCACAGTCGAGGCT; Chat $^{\text {Cre }}$ allele, F: CCTTCTATCGCCTTCTTGA CG, R: AGATAGATAATGAGGGGCTC; Chat wild-type locus, F: CCAA CCAAGCCAAGCAATCT, R: ATAGGGGAGCAGCAACAGC; Ai27 and Ai32 Rosa26 locus common primer, F: TCGTGATCTGCAACTCCA GTCTT; Rosa26 modified locus-specific primer, R: TGGGCTATGA ACTAATGACCCC; Rosa26 WT locus-specific primer, R: CGCCCA CACACCAGGTTAG.

Quantitative PCR. Quantitative PCR (qPCR) was performed for the $\alpha 3, \alpha 5$, and $\beta 4$ acetylcholine receptor and phosphoglycerate kinase 1 (Pgk1) transcripts. Relative mRNA levels are inversely proportional to the PCR cycle number and were calculated by the cycle threshold difference method (Livak and Schmittgen, 2001). All receptor mRNA levels were normalized to Pgk1 mRNA expression in each cell type to correct for small variations in mRNA content between the samples. Primers included $\alpha 3$ primers spanning exons 4 and 5, F: TCGTGCTTTACAAC AACGCC, R: CAAACGGGAAGTAGGTCACATC; $\alpha 5$ primers spanning exons 2 and 3, F: TTCGTCCTGTGGAACACCTG, R: GGTGGTCATT AGCTGGTTTTTCT; $\beta 4$ primers spanning exons 2 and 3 , F: TGGATG ATCTCCTGAACAAAACC, R: GTTCTCGCTCATTCACACTGAT; and Pgk1 primers spanning exons 5 and 6, F: GATGCTTTTGGGACTGCA CA, R: GCAGATTCACACCCACCATG.

Microarray analysis was performed on RNA samples from embryonic day 16.5 (E16.5) mouse embryos using Affymetrix 430v2 arrays as described previously (Quina et al., 2009). The $\alpha 5$ coding sequence (CDS) in situ hybridization (ISH) probe was Thermo Fisher Scientific/Open Bio- systems clone ID number 40046382 (708 bp), corresponding to positions $827-1534$ of the $\alpha 5$ reference mRNA sequence (GenBank accession number NM_176844_4). The $\alpha 53^{\prime}$-untranslated ISH probe, corresponding to positions $1549-2511$ of the reference mRNA sequence, was generated by RT-PCR. The ISH probe for $\beta 4$ was a gift from Dr. Silke Frahm-Barske (Max Delbrueck Centrum, Berlin, Germany) (Frahm et al., 2011). Double-label fluorescence in situ hybridization (DFISH) was performed on a high-throughput platform as described previously (Thompson et al., 2008). Sequences used to generate FISH probes for Gad1, Slc17a6, Chrna5, and Sst are the same as those used to generate ISH data for the Allen Mouse Brain Atlas (ABA) and are available online at: http://mouse.brain-map.org/search/index.

Tract tracing and immunofluorescence. Retrograde tract tracing was performed using a $1 \%$ solution of cholera toxin B subunit (CTB; List Biological Labs), injected using standard stereotaxic coordinates (Paxinos and Franklin, 2001). Large areal injections of CTB were performed by pressure injection using a 33 ga stainless steel needle, whereas small focal injections were performed by iontopheresis using a pulled glass pipette, using published methods (Harris et al., 2012). Antibodies for immunofluorescence were obtained from the following sources: rabbit anti-GFP (1:500), Invitrogen; goat anti-GFP (1:500), Thermo Fisher Scientific/ Pierce; chicken anti-GFP (1:500), Aves Labs; goat anti-choline acetyltransferase (ChAT; 1:100), rat monoclonal anti-substance P (SP; 1:200), rabbit anti-tyrosine hydroxylase (1:500), and rabbit anti-tryptophan hydroxylase 2 (Tph2; 1:500), Millipore; goat anti-CTB (1:1000), List Biological Labs; rabbit anti-CTB (1:1000), Abcam; rabbit anti-calretinin (1: 500) and rabbit anti-parvalbumin (1:500), Swant; and rabbit antisomatostatin (1:500), Bachem/Peninsula Labs. Preparation and use of rabbit (Fedtsova and Turner, 1995) and guinea pig (Quina et al., 2005) antisera to mouse Brn3a have been described previously.

Electrophysiology methods. Adult mice of both genders (8-30 weeks of age) were used for electrophysiology. For the preparation of acute brain slices used in loose-seal cell-attached recordings, mice were anesthetized with isoflurane and quickly decapitated, and the whole brains were dissected into cold artificial CSF (aCSF) containing (in mM) $118 \mathrm{NaCl}, 3$ $\mathrm{KCl}, 25 \mathrm{NaHCO}_{3}, 1 \mathrm{NaH}_{2} \mathrm{PO}_{4}, 1 \mathrm{MgCl}_{2}, 1.5 \mathrm{CaCl}_{2}$, and 10 glucose, $\mathrm{pH}$ 7.4. Coronal brain slices $(350 \mu \mathrm{m})$ were cut with a vibratome (VT1000S; Leica) in cold oxygenated aCSF, and slices were allowed to recover for at least $30 \mathrm{~min}$ at room temperature in oxygenated aCSF before transferring to the recording chamber. During recording, slices were superfused with aCSF at $30^{\circ} \mathrm{C}$.

For the preparation of acute brain slices used in intracellular recordings, mice were anesthetized with isoflurane, injected intraperitoneally with pentobarbital $(120 \mathrm{mg} / \mathrm{kg}$ ), and perfused transcardially with $\sim 10 \mathrm{ml}$ of ice-cold oxygenated sucrose slicing solution (SSS). The SSS contained (in mM) 210 sucrose, $5 \mathrm{KCl}, 1.25 \mathrm{NaH}_{2} \mathrm{PO}_{4}, 3.5 \mathrm{MgSO}_{4}, 0.5 \mathrm{CaCl}_{2}, 26$ $\mathrm{NaHCO}_{3}$, and 10 glucose, pH 7.4 with $\mathrm{HCl}$. Mice were quickly decapitated, and whole brains were dissected into cold oxygenated SSS. Coronal brain slices $(350 \mu \mathrm{m})$ were cut in a vibratome in cold oxygenated SSS and transferred to recover in oxygenated SSS at room temperature for $45 \mathrm{~min}$. Slices were then allowed to recover for at least $1 \mathrm{~h}$ at room temperature in oxygenated aCSF (as above, except with $30 \mathrm{~mm}$ glucose) before transferring to the recording chamber. During recording, slices were superfused with $30 \mathrm{~mm}$ glucose aCSF at $30^{\circ} \mathrm{C}$.

Loose-seal cell-attached recordings from $\mathrm{vMHb}$ neurons were obtained using the blind-patch technique in slice preparations using brightfield optics to visualize the habenula. Cholinergic neurons expressing ChR2 in the vMHb of Chat ${ }^{\text {Cre }} / \mathrm{Ai} 32$ mice were identified based on the presence of light-induced action potentials. Recording electrodes (3-7 $\mathrm{M} \Omega$ ) were filled with $10 \mathrm{~mm}$ glucose aCSF, and recordings were obtained with a MultiClamp 700B Amplifier (Molecular Devices), connected to a digitizing interface (Digidata 1440), and analyzed with pClamp 10.2. For patch-clamp recording from cholinergic neurons in the vMHb and $\alpha 5^{\mathrm{GPP}}$ neurons in the IP, electrodes (3-7 M $\Omega$ ) were filled with an internal solution containing (in mM) $140 \mathrm{~K}$-gluconate acid, $1 \mathrm{CaCl}_{2}, 2 \mathrm{MgSO}_{4}, 10$ EGTA, $4 \mathrm{Na}_{2}$-ATP, $0.3 \mathrm{Na}-\mathrm{GTP}$, and 10 HEPES, pH 7.2. In whole-cell voltage clamp mode, vMHb neurons were held at $-60 \mathrm{mV}$ and IP neurons at $-80 \mathrm{mV}$. A low-pass filter $(250 \mathrm{~Hz})$ was applied to selective records to remove movement artifacts. Optical stimulation of brain 
slice preparations to activate ChR2 was supplied by a $447 \mathrm{~nm}$ blue laser (OptoEngine) coupled to a $200 \mu \mathrm{m}, 0.22 \mathrm{NA}$ optical fiber (Thor Labs). The optical fiber was submerged in aCSF with its bare fiber end placed $5 \mathrm{~mm}$ from the habenula $\left(2.0 \mathrm{~mW} / \mathrm{mm}^{2}\right)$ or $2 \mathrm{~mm}(9.7 \mathrm{~mW} /$ $\mathrm{mm}^{2}$ ) from the IP.

For drug application, DNQX (10 $\mu \mathrm{M})$, D-AP-5 (50 $\mu \mathrm{M})$, dihydro- $\beta$ erythroidine hydrobromide $(\mathrm{DH} \beta \mathrm{E} ; 10 \mu \mathrm{M})$, SR16584 $(20 \mu \mathrm{M})$, and mecamylamine $(5 \mu \mathrm{M})$ were bath applied to the circulating aCSF by diluting a stock solution. Standardized pulses of nicotine $(0.5 \mu \mathrm{M})$ were applied by controlled positive-pressure pulses, delivered through a picospritzer and a pulled glass pipette. All drugs were purchased from Tocris Bioscience.

To assess for a synaptic connection between vMHb neurons and $\alpha 5$ expressing neurons in the IP, coronal sections were prepared from Chat ${ }^{\mathrm{Cre}} / \mathrm{Ai} 27, \alpha 5^{\mathrm{GFP}}$ or Chat ${ }^{\mathrm{Cre}} / \mathrm{Ai} 32, \alpha 5^{\mathrm{GFP}}$ transgenic mice at a plane of section containing vMHb fiber terminals and rostral IP (IPR) cell bodies (bregma, $-3.4 \pm 0.2 \mathrm{~mm}$ ). Neurons expressing $\alpha 5^{\mathrm{GFP}}$ were identified for recording using epifluorescence of the cytoplasmic GFP marker. Before laser stimulation, a 2 min continuous recording was performed to determine baseline activity, followed by 100-150 control traces consisting of $1 \mathrm{~s}$ recordings with a $2 \mathrm{~s}$ intersweep interval between recorded traces. For the laser stimulation protocol, identical 100-150 $1 \mathrm{~s}$ traces were recorded, but with a $10 \mathrm{~ms}$ laser pulse at the beginning of each trace. The role of glutamatergic signaling was tested by bath application of the glutamatergic inhibitors DNQX and D-AP-5, and the laser stimulation protocol was repeated $10 \mathrm{~min}$ after drug application. Each slice was used for one to three recordings; for slices from which multiple cells were recorded, aCSF was superfused for at least $30 \mathrm{~min}$ between recordings to wash out the applied drugs. Recordings were manually scored for the presence of EPSCs, EPSC latencies, and amplitudes from 0 to $13.9 \mathrm{~ms}$ after the onset of the $10 \mathrm{~ms}$ laser pulse, in both laser-stimulated and control traces. A 60-80 s recording before light stimulation was used to calculate the mean baseline amplitude. EPSCs with amplitudes $<2$ SDs from the mean baseline amplitude were assumed to be noise and were not included in the analysis. To determine the nicotinic receptor pharmacology of $\alpha 5^{\mathrm{GFP}}$ neurons in the IP, coronal sections were prepared from $\alpha 5^{\mathrm{GFP}}$ transgenic mice.

For pharmacological studies of nicotine responses in the $\mathrm{vMHb}$, coronal sections were prepared from $\mathrm{Chat}{ }^{\mathrm{Cre}} / \mathrm{Ai} 32$ transgenic mice, which express an EYFP marker in cholinergic neurons in the $\mathrm{vMHb}$, allowing these cells to be identified for patch-clamp recording in the slice preparation by fluorescence microscopy. The $\alpha 5^{\mathrm{GFP}}$ IP neurons were similarly identified in coronal sections by their GFP fluorescence. Nicotine $(0.5$ $\mathrm{mm}$ ) was pressure applied in brief pulses (90 ms, 10-12 psi) every $3 \mathrm{~min}$ to avoid receptor desensitization, using established methods (Xiao et al., 2009). Once the cells reached a stable response to the nicotine application, four to six inward current responses were averaged to be the baseline response before bath application of the antagonist. Responses to the antagonist were assessed beginning $10 \mathrm{~min}$ after application, and three to nine current responses were acquired once the nicotine response of the cells stabilized in the presence of the antagonist. Responses to drug recovery were assessed 10 or 30 min after switching to aCSF. The average nicotine-evoked current during antagonist application and recovery was normalized to the average baseline nicotineevoked current for each neuron. Since effects of mecamylamine and $\mathrm{DH} \beta \mathrm{E}$ are reversible, brain sections were reused once for those experiments after at least $30 \mathrm{~min}$ of washout in aCSF. Fresh brain sections were used for SR16584 experiments.

Statistical analyses. Paired $t$ tests were used for analyzing the effects of light-evoked EPSCs recorded from individual $\alpha 5^{\text {GFP }}$ IP neurons. The Friedman test and the Dunn's multiple comparisons test were used for analyzing the effects of mecamylamine and SR16584 on nicotine responses in vMHb neurons. Wilcoxon tests were used for analyzing the effects of $\mathrm{DH} \beta \mathrm{E}$ and SR16584 on nicotine responses from individual $\alpha 5^{\text {GFP }}$ IP neurons. Statistical analyses were performed using GraphPad Prism 6 software. Results are presented as means (SD).

\section{Results}

\section{Identity of $\mathrm{nAChR} \alpha 5$ subunit-expressing neurons in the habenulo-peduncular-tegmental system}

Identification of the specific neurons in which the $\alpha 5 \mathrm{nAChR}$ subunit is expressed is essential for two principal reasons. First, because it is an accessory subunit, the effect of $\alpha 5$ on nAChR function depends entirely on the specific channel-forming/ ligand-binding subunits with which it is assembled (Lindstrom et al., 1996; Ramirez-Latorre et al., 1996; Nelson and Lindstrom, 1999), and the available partners are cell specific. Second, cellular resolution is necessary to identify $\alpha 5$-expressing neurons in brain nuclei containing diverse cell types, such as the IP and MnR, to understand how these neurons may assemble into functional circuits. Three principal methods have been used to describe the expression of nAChRs in the brain: in situ hybridization, receptor autoradiography, and receptor binding in brain homogenates, which have not provided cellular resolution. There are no published reports of $\alpha 5$ subunit localization by immunohistochemistry, presumably because the available antibodies are not suitable for this purpose. Here, we have overcome these limitations by using an $\alpha 5^{\mathrm{GFP}}$ BAC transgene (GENSAT), examined by immunofluorescence for the expressed GFP and by cellular-resolution FISH to examine the neurotransmitter phenotype and circuitry of $\alpha 5$-expressing neurons in the brainstem.

To understand the expression of $\alpha 5$ at the cellular level, we first examined the expression of a GFP reporter in $\alpha 5^{\mathrm{GFP}}$ mice and compared it with the pattern of $\alpha 5$ mRNA in the ABA. In the telencephalon, $\alpha 5^{\mathrm{GFP}}$-labeled cell bodies were observed in the neocortex (layers 5 and 6), endopiriform nucleus, subiculum, and CA1 region of the hippocampus (Fig. $1 A-F$ and data not shown), entirely in agreement with ABA data. In contrast, no cell body or fiber staining was noted in the medial or lateral habenula (LHb; Fig. 1G,I), also in agreement with ABA data. However, the $\alpha 5^{\mathrm{GFP}}$ transgene did not replicate the known expression of $\alpha 5$ mRNA in the VTA and substantia nigra (Fig. $1 J-L$; Wada et al., 1990). This specific lack of expression of $\alpha 5^{\mathrm{GFP}}$ in these midbrain dopaminergic nuclei could occur because the required Chrna5 gene regulatory sequences lie outside the BAC used to generate the transgene. Axonal transport of GFP also allowed visualization of the major projections of the $\alpha 5^{\mathrm{GFP}}$ neurons. Fiber labeling, but no cell bodies, were seen prominently in thalamic regions, including the laterodorsal, central medial, ventrolateral, and ventromedial nuclei, representing the expected projections of the cortical layer 5-6 neurons (data not shown).

Numerous $\alpha 5^{\mathrm{GFP}}$ cell bodies were observed in the IP, consistent with database ISH data (Fig. $2 A-C$ ). The $\alpha 5^{\mathrm{GFP}}$-labeled cells were concentrated in the IPR, encompassing part of the region that receives intense cholinergic input from the vMHb (Fig. $2 B, D-F)$. Occasional $\alpha 5^{\text {GFP }}$ cells were also observed in the caudal IP (IPC) but not in the lateral IP (IPL), which receives SPimmunoreactive fibers from the dorsal MHb (Fig. 2G,H). The most caudal part of the IP contained few $\alpha 5^{\text {GFP }}$ neurons (Fig. $2 I$ ), but at this level, scattered cells and GFP fiber staining were observed in the MnR.

The $\alpha 5^{\mathrm{GFP}}$-expressing neurons were also detected more caudally in the brainstem in the MnR and adjacent PMnR and in the DRI (Fig. $3 A-I$ ) but not in the principal part of the dorsal raphe or the central nucleus of the dorsal tegmentum (DTgC). In the raphe areas where they were observed, $\alpha 5^{\mathrm{GFP}}$ neurons were distinct from, but adjacent to, the serotonergic cell population marked by the expression of the enzyme Tph2 (Fig. 3C, E, $H$ ). In the laterodorsal tegmental nucleus (LDTg), $\alpha 5$ GFP neurons were 

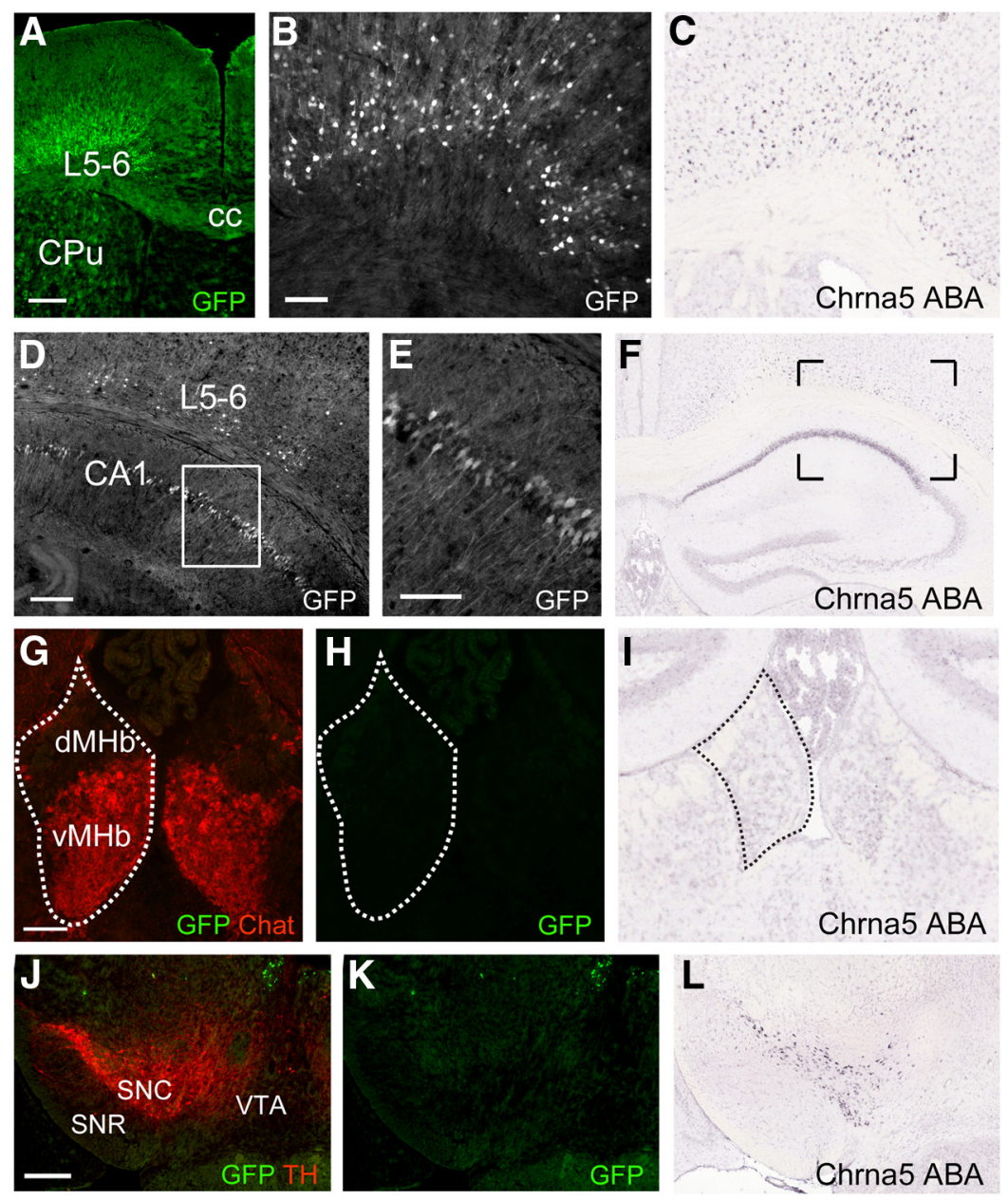

Figure 1. Expression of $\alpha 5^{\mathrm{GFP}}$ and $\alpha 5$ mRNA in the forebrain and rostral brainstem. $\boldsymbol{A}-\boldsymbol{C}$, Expression of $\alpha 5^{\mathrm{GFP}}(\boldsymbol{A}, \boldsymbol{B})$ and $\alpha 5(\boldsymbol{C})$ mRNA in the rostral cerebral cortex. $\boldsymbol{D}-\boldsymbol{F}$, Expression of $\alpha 5^{\mathrm{GFP}}(\boldsymbol{D}, \boldsymbol{E})$ and $\alpha 5(\boldsymbol{F}) \mathrm{mRNA}$ in the hippocampus. The boxed area in $\boldsymbol{F}$ corresponds to the region shown in $\boldsymbol{D}$. $\mathbf{G}-\boldsymbol{I}$, Expression of $\alpha 5^{\mathrm{GFP}}(\mathbf{G}, \boldsymbol{H})$ and mRNA $(\boldsymbol{I})$ in the habenula (not detected). Immunofluorescence for ChAT reveals cholinergic neurons in the vMHb. $\boldsymbol{J}-\boldsymbol{L}$, Expression of $\alpha 5^{\mathrm{GFP}}(\boldsymbol{J}, \boldsymbol{K})$ and $\alpha 5(\boldsymbol{L}) \mathrm{mRNA}$ in the VTA. Immunofluorescence for tyrosine hydroxylase reveals the location of the dopaminergic neurons in the VTA. In situ hybridization views are derived from the ABA dataset. CA1, Hippocampus region CA1; cc, corpus callosum; CPu, caudate/putamen; dMHb, medial habenula, dorsal part; L5-6, cortical lamina 5-6; SNC, substantia nigra, pars compacta; SNR, substantia nigra, pars reticulata. Scale bars: $\boldsymbol{A}, \boldsymbol{J}, \boldsymbol{K}, 400 \mu \mathrm{m} ; \boldsymbol{D}, 200 \mu \mathrm{m} ; \boldsymbol{B}, \boldsymbol{E}, \boldsymbol{G}, \boldsymbol{H}, 100 \mu \mathrm{m}$. ABA views are shown at approximately the same scale as the corresponding immunofluorescence images.

seen to be intermingled with the cholinergic neurons that characterize this region (Fig. $3 \mathrm{~J}, \mathrm{~K}$ ). The most caudal expression of $\alpha 5^{\mathrm{GFP}}$ was in the posterior dorsal tegmental nucleus (PDTg; Fig. $3 L-N)$. In each of these brainstem areas, there was strong correlation between the distribution of the $\alpha 5^{\text {GFP }}$ signal and $\alpha 5$ mRNA expression.

\section{Expression of the Chrn $\alpha 3 / \beta 4 / \alpha 5$ gene family in the habenulopeduncular system}

The MHb has been proposed as a critical site of action of the $\alpha 5$ receptor subunit in nicotine-related behaviors, yet $\alpha 5^{\mathrm{GFP}}$ was not detected in this nucleus, even with immunofluorescent enhancement of the GFP signal. Prior studies have reported mixed findings on the expression of $\alpha 5$ mRNA in the MHb. The initial report of $\alpha 5$ cloning in the rat showed $\alpha 5$ mRNA expression in lamina 5-6 of the neocortex, the subiculum, IP, ventral tegmental area (VTA), and substantia nigra, pars compacta (SNc) of the adult rat but reported that it was not detected in the $\mathrm{MHb}$ (Boulter et al., 1990). Subsequent in situ hybridization studies using the same rat full-coding probe in mouse tissue reported low levels of $\alpha 5$ mRNA expression in the MHb (Marks et al., 1992; Winzer-Serhan and Leslie, 2005; Heath et al., 2010). Studies using fullcoding probes for $\alpha 5$ in the MHb, especially across species, should be interpreted with caution because $\beta 2, \beta 3, \beta 4$, and $\alpha 3$ transcripts are also expressed in this nucleus (Allen Institute for Brain Science, 2012), and cross-hybridization must be considered. Thus, to reconcile $\alpha 5^{\mathrm{GFP}}$ expression with that of the endogenous gene, we reexamined expression of the $\alpha 5$ mRNA by in situ hybridization and compared expression of the clustered Chrna3/ b4/a5 gene transcripts by qPCR in the brain regions of interest.

To design a probe with complete specificity for $\alpha 5$, we amplified $\alpha 5$ cDNA fragments from the CDS and the $3^{\prime}$-UTR from adult mouse interpeduncular nucleus RNA by RT-PCR (Fig. 4A). To verify that the predicted 3 '-UTR sequence was transcribed at levels similar to the coding part of the $\alpha 5$ transcript, we compared the expression of the $3^{\prime}$-UTR and coding sequences by qPCR (see Materials and Methods). Expression levels of the coding and noncoding sequences matched within one to two amplification cycles. Nonisotopic in situ hybridization with the $\alpha 5$ CDS and 3 '-UTR probes gave a strong signal in the IP (Fig. 4B-D). Neither probe alone, nor a combination of the probes, gave a detectable signal in the MHb (Fig. $4 E)$.

In a previous study, we used microarrays and bioinformatic analysis of the E16.5 MHb to detect transcripts enriched in the $\mathrm{MHb}$ relative to other brain regions and genes that are developmentally regulated in the MHb by the transcription factor Brn3a, encoded by the Pou4f1 gene (Quina et al., 2009). The microarrays used in these studies provide independent expression data for most of the nAChR subunits (Fig. 4F). At E16.5, $\alpha 3$ and $\beta 4$ transcripts are robustly expressed and are markedly decreased in the Pou $4 f 1$ knock-out. Both $\alpha 5$ probe sets on the array, one corresponding to the CDS and one encompassing the $3^{\prime}$ UTR, showed undetectable levels of expression.

To better quantify the relative expression of $\alpha 5$ mRNA in the adult brain regions of interest, we performed qPCR using primer pairs specific for $\alpha 3, \beta 4$, and $\alpha 5$ transcripts (Fig. $4 G, H$ ). Expression of $\alpha 5$ mRNA in the MHb was $\sim 3.5 \%$ of that observed in the IP. Although low, this ratio probably still overestimates the cellspecific expression of $\alpha 5$ in the MHb relative to the IP because the cells sampled in the $\mathrm{MHb}$ are much more homogenous. The fraction of cells expressing $\alpha 5$ in the MHb sample could not be estimated because expression could not be detected at the cellular level. Conversely, $\alpha 3$ and $\beta 4$ mRNA levels in the IP were only $\sim 2 \%$ and $\sim 3 \%$ of the MHb levels, respectively. We conclude that the absence of detectable GFP expression in the MHb of $\alpha 5^{\mathrm{GFP}}$ mice is consistent with the very low levels of $\alpha 5$ mRNA expressed 
there and is not attributable to an artifact of low $\alpha 5^{\mathrm{GFP}}$ transgene expression. While mRNA abundance does not perfectly predict receptor expression caused by possible post-transcriptional effects on protein levels, it is thus likely that $\alpha 5$ subunits are much more abundant in the IP than in the $\mathrm{MHb}$.

\section{Neurotransmitter phenotypes of $\alpha 5$-expressing neurons}

To understand the role of $\alpha 5$-expressing neurons in regulating behavioral pathways, we next examined the principal neurotransmitter phenotype of these cells. None of the $\alpha 5$-expressing cell groups in the CNS expressed ChAT (Fig. $3 J-N$ and data not shown), indicating that $\alpha 5$-expressing neurons are not themselves cholinergic and that the $\alpha 5$ subunit is integrated into postsynaptic receptor complexes, not presynaptic autoreceptors. In the SNc and VTA, the anatomical expression pattern of $\alpha 5$ mRNA is consistent with expression in dopaminergic neurons (Boulter et al., 1990), but this was not assessed directly because the $\alpha 5^{\mathrm{GFP}}$ transgene was poorly expressed in this region. In the remainder of the brainstem, $\alpha 5^{\text {GFP }}$ did not colocalize with tyrosine hydroxylase (dopaminergic, noradrenergic neurons) or Tph2 (5-HT neurons), indicating that is not expressed in monoaminergic cells outside of the SNc/VTA (Fig. $3 A-H$ and data not shown).

To determine the principal neurotransmitter phenotype of $\alpha 5$-expressing neurons throughout the neural axis, we used DFISH (Thompson et al., 2008) to examine the coexpression of $\alpha 5 \mathrm{mRNA}$ with the GABAergic marker Gad1(Gad67), the brainstem glutamatergic marker Slc17a6 (Vglut2), and the neuropeptide cotransmitter somatostatin (Sst). In the forebrain, $\alpha 5^{+}$layer 5-6 cortical neurons that project to the thalamus are, as expected, Gad1 negative and therefore glutamatergic (data not shown). The $\alpha 5^{+}$neurons in the ventral subiculum also show no overlap with the $\mathrm{Gad} 1^{+}$interneuron population there (Fig. 5A).

In the IP, essentially all $\alpha 5^{+}$neurons were also Gad $1^{+}$(Fig. $5 B)$. Conversely, most GABAergic neurons in IPR were $\alpha 5^{+}$, but GABAergic neurons in IPC and IPL were mostly $\alpha 5$ negative. Although Slc17a6 ${ }^{+}$neurons were intermingled with $\alpha 5^{+}$neurons in the IPR, colocalization of these markers was not observed (Fig. 5C). Likewise in the MnR/PMnR and DRC/DRI, where $\alpha 5^{+}$ cells lie adjacent to 5-HT neurons, essentially all of the $\alpha 5^{+}$neurons also expressed Gad1 (Fig. 5D). We conclude that in the brainstem, $\alpha 5$ expression defines a subset of GABAergic neurons.

In the neocortex, subclasses of GABAergic neurons have been distinguished by the expression of the calcium-binding proteins parvalbumin and calretinin and by neuropeptides, particularly Sst, vasointestinal active peptide, and cholecystokinin (Xu and Callaway, 2009). We examined these markers using DFISH and immunofluorescence in $\alpha 5^{\mathrm{GFP}}$ mice to determine whether they also distinguish subsets of GABAergic neurons in the IP or colo- calize with $\alpha 5$. A small number of neurons in the most dorsal part of the IPR coexpress Sst and $\alpha 5$ mRNA (Fig. $5 E$ ). Parvalbumin immunoreactivity identifies a subset of IP neurons, but these are $\alpha 5^{\mathrm{GFP}}$ negative (Fig. $5 F$ ), whereas anti-calretinin antisera stained afferent fibers but not cell bodies in the IP (data not shown). Brn3a is also expressed in a subset of neurons in the IPR and IPL, but these are $\alpha 5^{\text {GFP }}$ negative (Fig. 5G).

\section{Projections of $\alpha \mathbf{5}$ neurons link the IP and raphe}

To begin to understand the function of $\alpha 5$-expressing neurons in the IP, MnR, and DTg, we used transgenic anterograde tract tracing and retrograde tracing with CTB to identify the principal connections of these neurons. Transgenic tracing of $\alpha 5^{\mathrm{GFP}}$ labeled IP neurons shows that their axons project through the MnR to the DTg, both of which also include intrinsic $\alpha 5$ neurons (Fig. 6A). Thus, anterograde tracing of GFP-labeled fibers does not immediately reveal whether $\alpha 5$-expressing IP neurons project all the way to the DTg or terminate at intermediate targets. It is also not clear whether the $\alpha 5$ neurons in the MnR and DTg project rostrally, caudally, or locally.

We then used stereotaxic injections of CTB to determine the specific projections of the $\alpha 5$-expressing neurons in the brainstem. CTB is a strong retrograde tracer but will also label fibers in an anterograde direction, yet it appears to label fibers of passage weakly or not at all (Luppi et al., 1990). Retrogradely labeled neurons were unambiguously identified by colocalization of CTB with GFP, which fills the cytoplasm of $\alpha 5^{\text {GFP }}$ neurons, using 

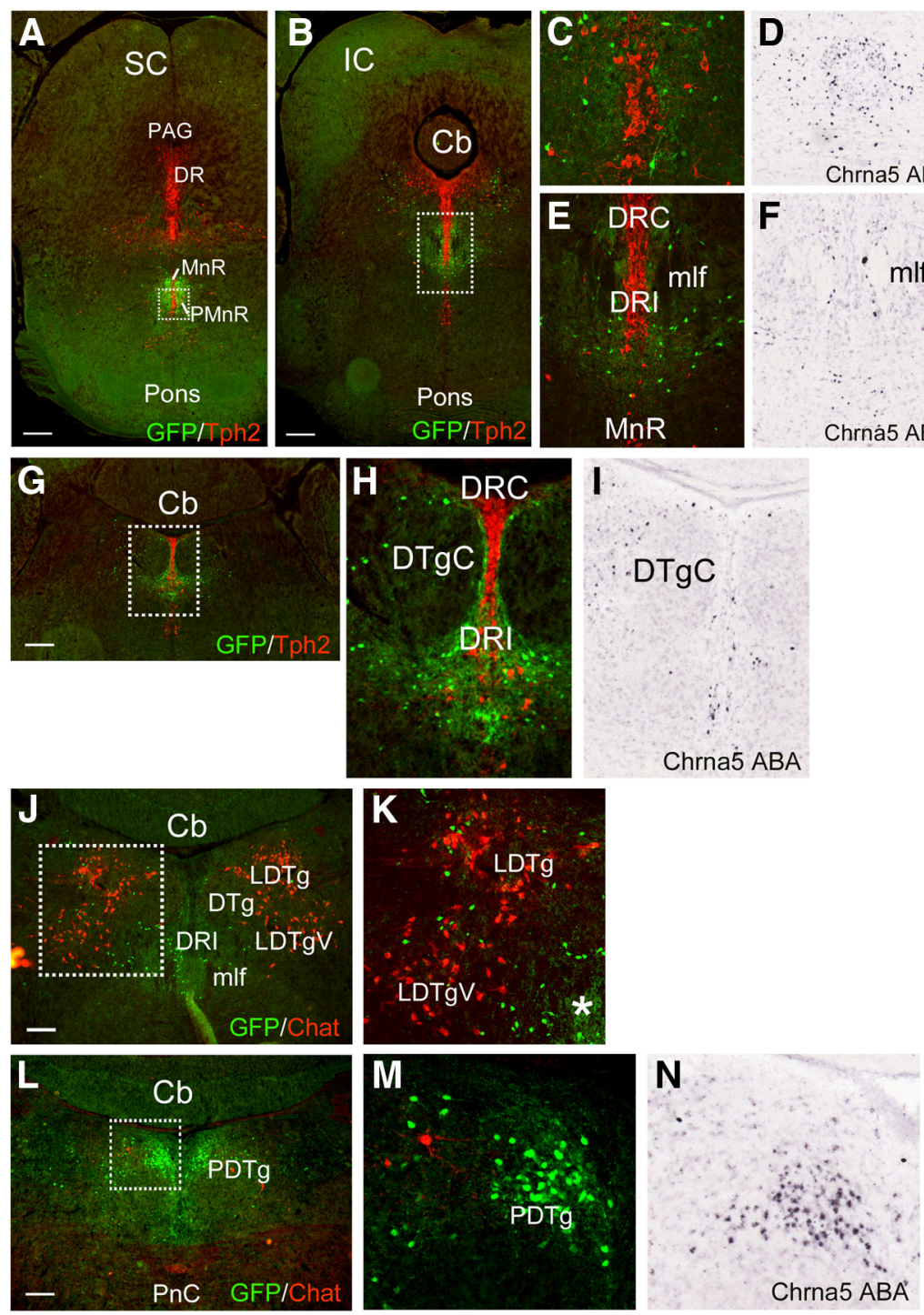

Figure 3. Expression of $\alpha 5^{\mathrm{GFP}}$ and $\alpha 5$ mRNA in the hindbrain raphe and dorsal tegmentum. Brains of adult $\alpha 5^{\mathrm{GFP}}$ mice were examined in coronal sections for the colocalization of GFP-labeled cells and fibers and markers of selected neurotransmitters. Data are shown from progressively more caudal levels. $\boldsymbol{A}$, Relationship of $\alpha 5^{\mathrm{GFP}}$ cells and fibers to 5 -HT neurons of the median raphe. $\boldsymbol{B}$, Relationship of $\alpha 5^{\mathrm{GFP}}$ cells and fibers to 5-HT neurons of the dorsal raphe. $C, D$, Enlargement of the boxed area in $A$ and the equivalent view from the $A B A$ showing $\alpha 5$ mRNA expression. $\boldsymbol{E}, \boldsymbol{F}$, Enlargement of the boxed area in $\boldsymbol{B}$ and the equivalent view from the ABA. $\mathbf{G}$, Relationship of $\alpha 5^{\text {GFP }}$ cells and fibers to 5 -HT neurons of the dorsal raphe, intrafascicular part. $\boldsymbol{H}, \boldsymbol{I}$, Enlargement of the boxed area in $\boldsymbol{G}$ and the equivalent view from the ABA.J, Relationship of $\alpha 5^{\mathrm{GFP}}$ cells and fibers to cholinergic neurons of the dorsal tegmental nucleus. $\boldsymbol{K}$, Enlargement of the boxed area in $J$. Fiber terminals near the dorsal raphe are indicated with an asterisk. $L, \alpha 5^{\mathrm{GFP}} \mathrm{GFP}$ cells and fibers in the posterodorsal tegmental nucleus. $\boldsymbol{M}, \boldsymbol{N}$, Enlargement of the boxed area in $\boldsymbol{L}$ and the equivalent view from the ABA. Cb, Cerebellum; DR, dorsal raphe; IC, inferior colliculus; LDTgV, lateral dorsal tegmental nucleus, ventral; mlf, medial longitudinal fasciculus; PAG, periaqueductal gray; PnC, pontine reticular nucleus, caudal; $S C$, superior colliculus. Scale bars: $A, B, 400 \mu \mathrm{m} ; \boldsymbol{G}, J, L, 200 \mu \mathrm{m}$. ABA views are shown at approximately the same scale as the corresponding immunofluorescence images.

confocal microscopy. Injection of CTB into the MnR (Fig. 6B) led to frequent labeling of $\alpha 5$-expressing neurons in the IPR (Fig. $6 C, D$ ). Injection of the DTg at the midline (Fig. $6 E$ ), an area that is populated with 5-HT neurons of the DRC/DRI, also led to frequent colabeling with $\alpha 5^{\mathrm{GFP}}$ in the IPR (Fig. 6F,G) and MnR (data not shown), confirming that $\alpha 5$-expressing IPR and MnR neurons project directly to this region. In single $(1 \mu \mathrm{m})$ confocal sections, the profiles of IPR $\alpha 5^{\mathrm{GFP}}$ neurons retrogradely labeled from the MnR and DTg revealed cell bodies typically $15-20 \mu \mathrm{m}$ in diameter that were often most intensely labeled with CTB at one pole, probably representing the origin of the axon (Fig.

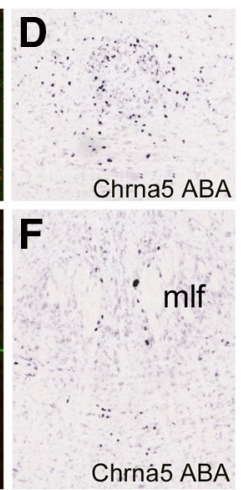

$6 \mathrm{H}, \mathrm{I})$. We note that a large fraction of the CTB-labeled neurons in IPR were $\alpha 5^{\text {GFP }}$ negative, consistent with the fact that $\alpha 5^{\mathrm{GFP}}$ is expressed in only a subset of the IPR neurons. The $\alpha 5^{\mathrm{GFP}} / \mathrm{CTB}$ doublelabeled neurons were smaller than some of the CTB-labeled cells that did not express $\alpha 5^{\mathrm{GFP}}$, consistent with the identity of the $\alpha 5^{\mathrm{GFP}}$ neurons as GABAergic interneurons (Fig. 5), which frequently have relatively small somas. We also note that many $\alpha 5^{\mathrm{GFP}}$ neurons remained unlabeled in each of these retrograde labeling cases. This is the expected result from a small, focal injection that only labels part of the overall IPR terminal field in MnR, DR, and DTg. In contrast, more lateral injections in the DTg (Fig. 6J), overlapping the region of the LDTg that contains cholinergic neurons (Fig. $6 \mathrm{~K}$ ) but avoiding the DRI (Fig. 6L), seldom labeled $\alpha 5^{\mathrm{GFP}}$ neurons in the IPR. Instead, retrograde labeling was seen in the dorsolateral IP (IPDL), mainly contralateral to the injection (Fig. $6 M, N)$. This region did not stain for $\alpha 5^{\mathrm{GPP}}$ and could be distinguished from the adjacent IPL by its lack of SP expression. Together, these data demonstrate that $\alpha 5$ expressing neurons in the IP terminate near 5-HT neurons throughout the MnR and DRC/DRI but represent only one class of IP neurons that terminate in these areas, intermingled with more numerous non- $\alpha 5^{\mathrm{GFP}}$ cells. In addition to the $\alpha 5^{\mathrm{GFP}}$ cell bodies in the IPR, we also noted GFP fiber staining in the IP, especially in IPC (Figs. 2G, 6M), suggesting that $\alpha 5$ neurons also supply afferents to the IP. Injections of CTB into the IP (Fig. $7 A$ ) produced intense labeling of both fibers (anterograde labeling) and cell bodies (retrograde labeling) in the MnR (data not shown) and the DTg/DRI (Fig. $7 B, D$ ). Confocal imaging of retrogradely transported $\mathrm{CTB}$ and $\alpha 5^{\mathrm{GFP}}$ revealed that $\alpha 5$ neurons in the PDTg (Fig. 7C) and in the region surrounding the 5-HT neurons of the DRI (Fig. $7 E, F)$ project to the IP. Thus, $\alpha 5^{\text {GFP }}$ neurons in the IP and the MnR/DRI form reciprocal connections between these regions (Fig. 7G).

\section{Optogenetically assisted circuit} mapping of the vMHb connection to $\alpha 5$-expressing IP neurons

Previous work has shown that vMHb neurons use both glutamate and acetylcholine as coneurotransmitters but that fast synaptic connections to IP neurons are mediated mainly by glutamate (Ren et al., 2011). The identities of the postsynaptic IP neurons recorded were not specifically characterized in this study. To assess the synaptic connection between vMHb neurons and $\alpha 5^{\mathrm{GFP}}$ neurons in the IP, we used optogenetically assisted circuit mapping. Specific expression of ChR2 in the vMHb was accomplished using a recently described Cre-inducible expres- 
A
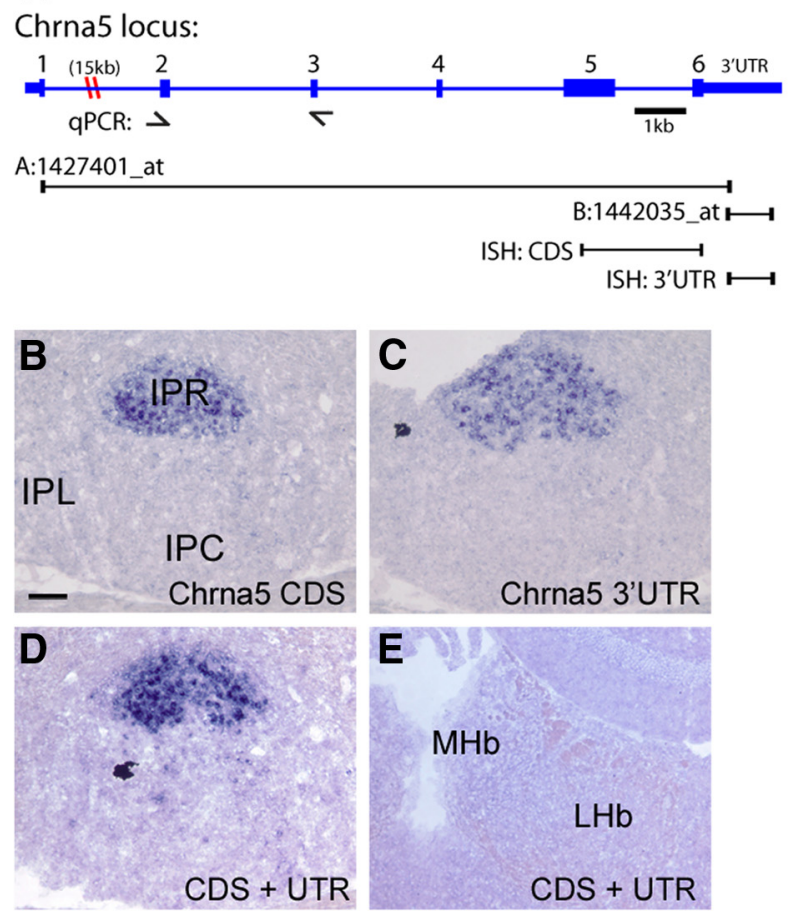

\section{F}

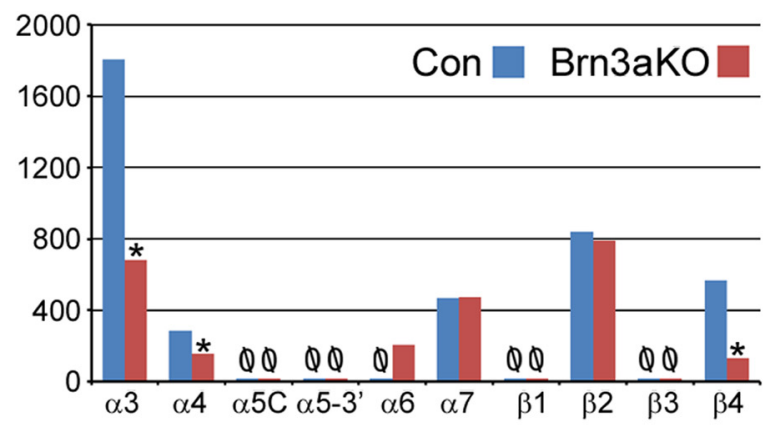

H

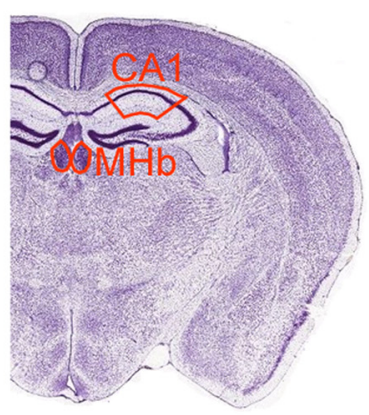

G
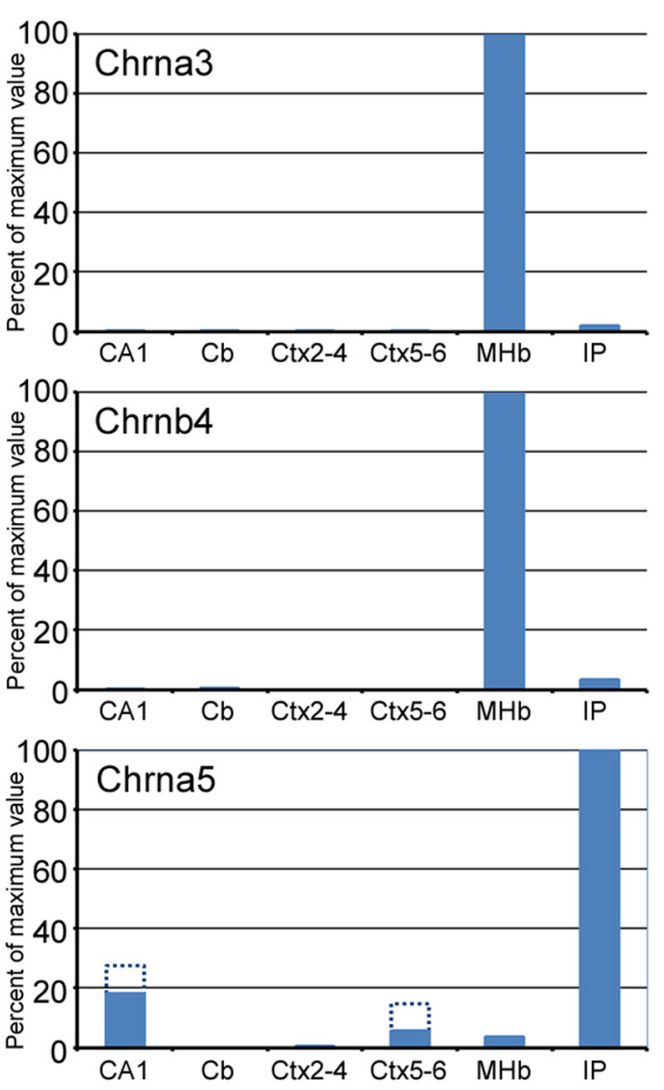

Figure 4. Regional brain expression of nAChR mRNAs. A, Map of the Chnra5 gene locus showing the location of qPCR primers, Affymetrix $430 \mathrm{v} 2$ array probe sets, and in situ hybridization probes to the Chrna5 coding sequence and $3^{\prime}$-untranslated region. $\boldsymbol{B}-\boldsymbol{E}$, In situ hybridization for $\alpha 5$ mRNA using individual and combined probes in the interpeduncular nucleus $(\boldsymbol{B}-\boldsymbol{D})$ and habenula $(\boldsymbol{E}) . \boldsymbol{F}$, Microarray assay of cholinergic receptor subtype mRNA expression in the E16.5 mouse habenula (medial plus lateral). Values shown are means of two independent experiments for each genotype. Null signs indicate "absent" calls, and asterisks indicate significant probability of change values using the Affymetrix MAS5.0 analysis platform, as described previously (Quina et al., 2009). Two probe sets for $\alpha 5, A: 1427401$ at ( $\alpha 5$ C) and B:1442035_at ( $\alpha 5-3^{\prime}$ ), appear on the array, neither of which has a signal above the detection threshold. The $\alpha 3, \alpha 4$, and $\beta 4$ are significantly decreased in the habenula of Brn3a null mice. $\mathbf{G}$, Real-time qPCR assays of regional brain expression of $\alpha 3, \beta 4$, and $\alpha 5$ mRNA in the hippocampus (CA1), cerebellum (Cb), cerebral cortex layers $2-4$ (Ctx2-4), cerebral cortex layers 5 and 6 (Ctx5-6), MHb, and IP. Results were scaled such that expression in the highest-expressing tissue equals $100 \%$. Dashed bars for Chrna 5 expression indicate values adjusted for the lower fraction of $\alpha 5$ GFP -expressing neurons in cortical layers 5 and 6 and the hippocampus relative to the IPN, to approximate the level of expression per $\alpha 5$-expressing cells. $\boldsymbol{H}$, Location of dissected tissues from vibratome sections used to prepare RNA for qPCR assays of nAChR expression. Cerebellum tissue was harvested as a block. Scale bars: $\boldsymbol{B}-\boldsymbol{E}, 100 \mu \mathrm{m}$. 

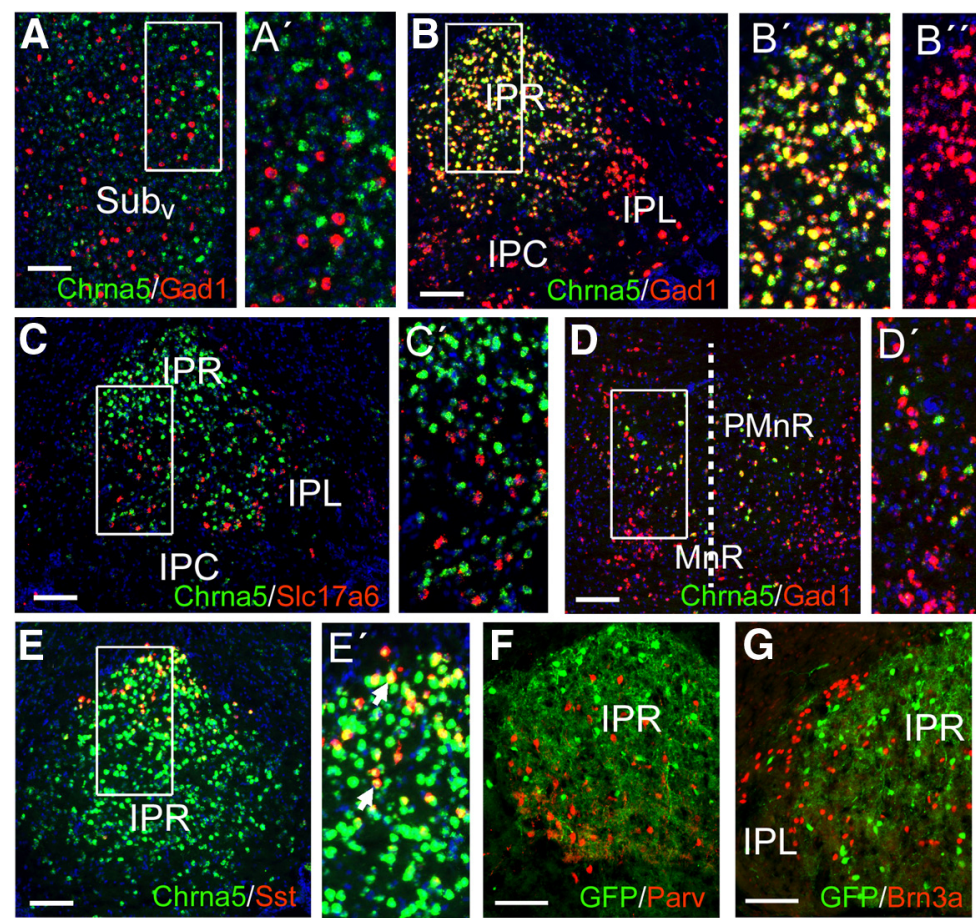

Figure 5. Neurotransmitter phenotype of $\alpha 5$-expressing neurons. DFISH $(\boldsymbol{A}-\boldsymbol{E})$ and immunofluorescence $(\boldsymbol{F}, \boldsymbol{G})$ were used to determine the colocalization of $\alpha 5$ mRNA with other markers in the IP and MnR. $A$, In the subiculum, $\alpha 5$ does not colocalize with Gad1, indicating that the $\alpha 5^{+}$neurons in this region are glutamatergic. Similar results were observed in layer 6 of the neocortex (not shown). $\boldsymbol{B}$, In the IPR, $>95 \%$ of $\alpha 5^{+}$neurons also express Gad1. C, DFISH for $\alpha 5$ and Slc17a6 (Vglut2) mRNA shows no colocalization in IPR, although glutamatergic neurons are present in the nucleus. $\boldsymbol{D}$, In the MnR/PMnR, $>95 \%$ of $\alpha 5^{+}$neurons coexpressed Gad1. The dashed line indicates the midline. $\boldsymbol{E}$, A small number of $\alpha 5^{+}$neurons in the apex of IPR were seen to coexpress $S$ st. $\boldsymbol{F}$, The $\alpha 5^{+}$neurons are negative for parvalbumin, which identifies a distinct subset of IPR neurons. $\boldsymbol{G}$, The $\alpha 5^{+}$ neurons are negative for the transcription factor Brn3a, which is expressed in a distinct population of IPR and IPL neurons. $\boldsymbol{A}^{\prime}-\boldsymbol{E}^{\prime}$, Enlargements of boxed areas in accompanying images. Sub , subiculum, ventral. Scale bars, $100 \mu \mathrm{m}$.

sion system based on microbial opsin genes targeted to the Gt(ROSA)26Sor locus (Madisen et al., 2012). In this study, we used the transgenic lines Ai27, which allows inducible expression of a Channelrhodopsin2(H134R)-tdTomato fusion gene product (ChR2-tdTomato), and Ai32, which allows expression of a ChR2-EYFP fusion gene product. Ai32 conferred somewhat higher light sensitivity, but the performance of the two ChR2 fusion proteins in electrophysiological experiments was similar. Expression of each $\mathrm{ChR} 2$ allele was induced by interbreeding with a Chat ${ }^{\text {Cre }}$ driver line containing an IRES-Cre expression construct targeted to the $3^{\prime}$-untranslated region of the Chat gene (Rossi et al., 2011). In mice with Chat ${ }^{\text {Cre }}$ induction of ChR2, expression of the transgene was confined to the $\mathrm{vMHb}$, with sparing of the dorsal $\mathrm{MHb}$ and the LHb (Fig. 8A). In the IP, ChR2labeled fibers were confined to the rostral and caudal parts of the IP (Fig. 8B), known to be the termination zone of cholinergic vMHb fibers (Eckenrode et al., 1987; Quina et al., 2009). For optogenetic circuit mapping, experimental animals had the genotype Ai27 (or Ai32), Chat ${ }^{\mathrm{Cre}}$, or $\alpha 5^{\mathrm{GFP}}$. The $\alpha 5^{\mathrm{GFP}}$-expressing IP neurons were readily visualized using GFP fluorescence in vibratome sections of brain tissue prepared for electrophysiology (Fig. 8C).

To test light activation of $\mathrm{ChR} 2$-expressing vMHb neurons, we first used loose-seal, cell-attached current-clamp recordings from vMHb cell bodies (Fig. 8D). At baseline, neurons in the $\mathrm{vMHb}$ exhibited slow, irregular tonic firing, consistent with previous reports of spontaneous habenula activity (Kim and Chang, 2005). Trains of blue light pulses elicited 1:1 spiking of action
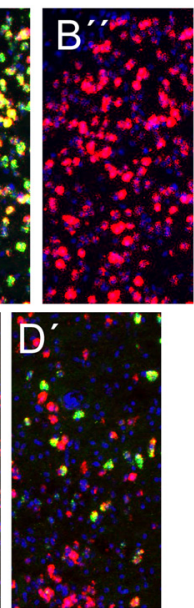

potentials from $\mathrm{vMHb}$ neurons at frequencies of up to $\sim 10 \mathrm{~Hz}$ (Fig. $8 D$ ). We then used whole-cell voltage-clamp recordings to measure light-evoked EPSCs in $\alpha 5$-expressing IP neurons. In oblique slice preparations that contained the intact habenulopeduncular system, including the vMHb, fasciculus retroflexus, and IP, very frequent spontaneous EPSCs were observed in IP neurons, presumably because of network activity (data not shown). To better isolate the light-evoked EPSCs caused by specific synaptic connections between the $\mathrm{vMHb}$ and the IP, experiments were performed in coronal sections through the IP, which included only the fiber terminals and not the cell bodies, of the vMHb glutamatergic/cholinergic neurons.

Light-evoked EPSCs recorded from individual $\alpha 5^{\text {GFP }}$ IP neurons frequently showed multiple consistent latencies and amplitudes, suggesting multiple $\mathrm{vMHb}$ synaptic inputs to a single cell (Fig. $8 E$ ). These light-evoked EPSCs generally occurred with latencies of 5-11 ms from the onset of a $10 \mathrm{~ms}$ light pulse. Median latencies of 5, 6.2, 6.5, 6.5, 8.5, and $9 \mathrm{~ms}$ were observed for the six cells characterized (the cell with a median latency of $9 \mathrm{~ms}$ is shown in Fig. $8 F$ ). The median latencies exhibited by these neurons are within the typical latencies for monosynaptic transmission elicited by optogenetic excitation of axon terminals across several studies (Piñol et al., 2012). In the sample of cells recorded, the probability of an EPSC occurring in the interval from 3 to $11 \mathrm{~ms}$ after a light pulse ranged from 0.16 to 0.94 , compared with $0.01-0.15$ for matched time intervals without laser stimulation $(p=0.01$, paired $t$ test; $n=6$; Fig. $8 G$ ). Both spontaneous and light-evoked EPSCs were entirely blocked by inhibitors of glutamatergic signaling (DNQX and D-AP-5), consistent with a previous study showing that glutamate mediates the fast synaptic connection from the vMHb to IP (Ren et al., 2011). We conclude that the $\mathrm{vMHb}$ and $\alpha 5$-expressing IP neurons form a direct synaptic circuit in which glutamate is the principal fast neurotransmitter. These results are consistent with a "neuromodulatory" role for acetylcholine in the IP, as described in other CNS regions (Picciotto et al., 2012).

Nicotinic receptor pharmacology of $\alpha 5^{\mathrm{GFP}}$ neurons in the IP The habenulopeduncular system has been hypothesized to regulate behavioral responses to nicotine. Because $\alpha 5$ is an accessory receptor subunit, the other $\alpha$ and $\beta$ nicotinic receptor subunits with which it interacts will determine the ligand-binding and ion channel properties of $\alpha 5$-containing receptors. In most areas of the brain in which it is expressed, $\alpha 5$ is likely to complex with the widely expressed receptor subunits $\alpha 4$ and $\beta 2$. However, it is unclear what subunits would interact with $\alpha 5$ in the IP and, specifically, whether sufficient $\alpha 3$ and $\beta 4$ subunits are expressed to allow for the possible formation of functional $\alpha 3 \beta 4$ complexes containing $\alpha 5$ subunits. The principal nAChRs reported from ligand-binding studies of IP homogenates contain $\alpha 3 \beta 4$ and 

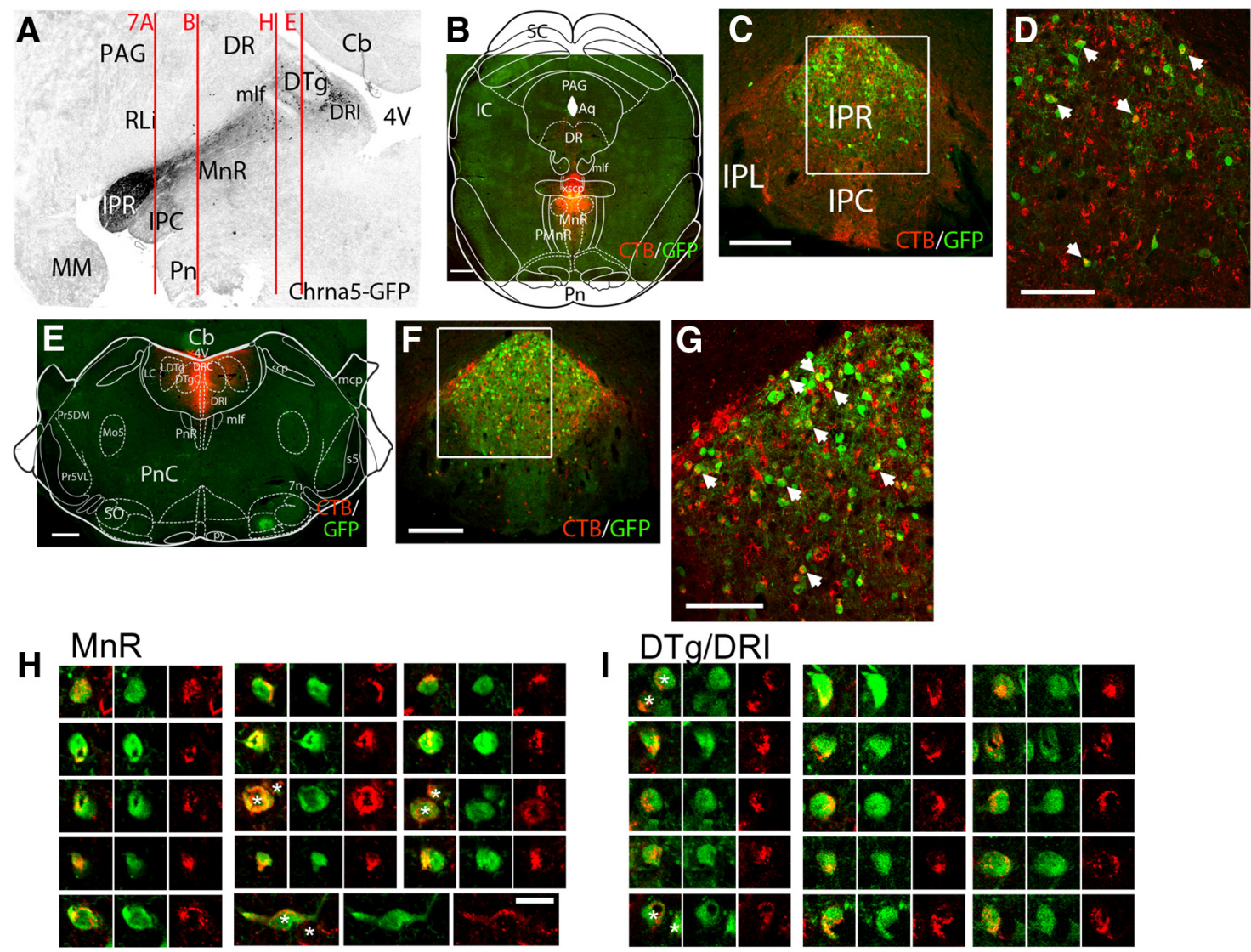

$\mathrm{DTg} / \mathrm{DRI}$
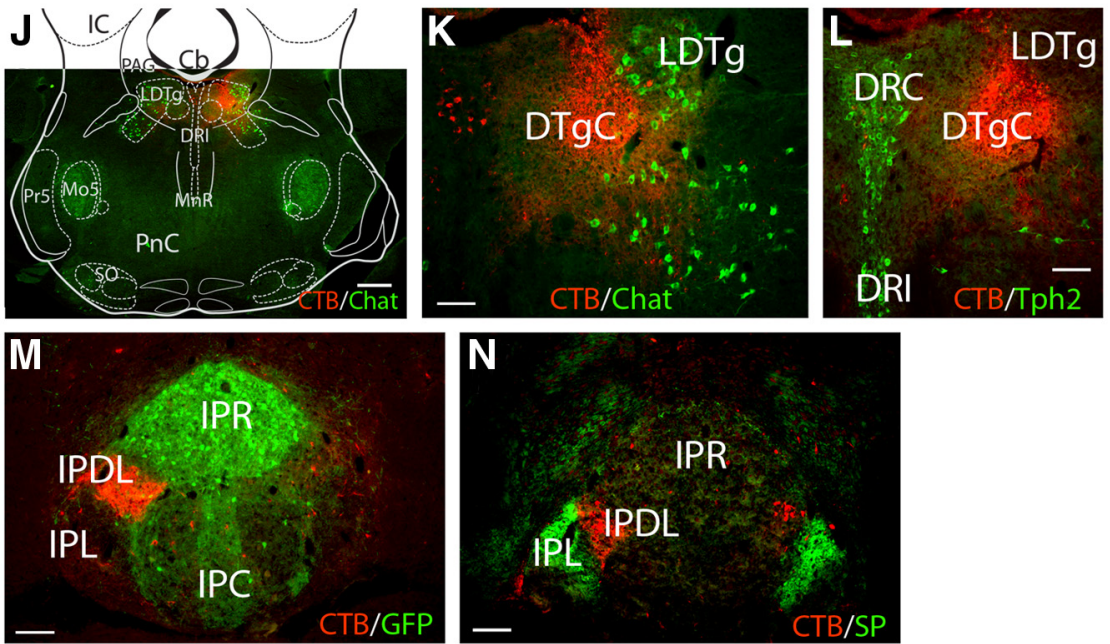

Figure 6. Caudal projections of $\alpha 5$-expressing neurons in the interpeduncular nucleus. Stereotaxic injections of CTB were used to trace the projections of $\alpha 5^{\text {GFP }}$ neurons in the brainstem. $A$, Sagittal view of the brainstem stained for $\alpha 5^{\text {GFP }}$; rostral is on the left. Lines show the planes of section for the injections shown in $\boldsymbol{B}, \boldsymbol{E}, \boldsymbol{H}$, and Figure $7 A$. $\boldsymbol{B}$, Location of injection site in MnR/dorsal raphe (plane of section at bregma, -4.4). C, D, Retrograde labeling of IPR neurons from MnR. In D, a Z-stack of $201 \mu \mathrm{m}$ optical sections is shown, and arrows indicate neurons double labeled for CTB and GFP (see also $\boldsymbol{H}$ ). $\boldsymbol{E}$, Location of injection site in the midline of the DTg (bregma, -5.3 ), an area populated with 5-HT neurons of the DRC/DRI, which can be seen in Figure $3 H$. $\boldsymbol{F}, \boldsymbol{G}$, Retrograde labeling of IPR neurons from the central DTg. In $\mathbf{G}$, a Z-stack of $201 \mu \mathrm{m}$ optical sections is shown, and arrows indicate neurons double labeled for (TB and GFP (see also I). $\boldsymbol{H}$, Images of single retrogradely labeled IP neurons from the case shown in $\boldsymbol{B}$. Single $1 \mu \mathrm{m}$ optical sections from a confocal Z-series are shown. Each triad of images show, from left to right, a merged image, $\alpha 5^{\text {GFP }}$, and CTB. Images in the left column are taken from the section shown in $\boldsymbol{D}$; images in the two right columns are taken from another section from the same case. $I$, Images of single retrogradely labeled IP neurons from the case shown in $\boldsymbol{E}$. Images in the left column are taken from the section shown in $\mathbf{G}$; images in the two right columns are taken from another section from the same case. All of the cell profiles in both cases are taken from the IPR. Asterisks in $\boldsymbol{H}$ and $/$ show the location of multiple cells in a single field, which may be labeled with $\alpha 5^{\text {GFP }}$, CTB, or both. J-L, Location of injection site in the lateral $\mathrm{DTg}$ (bregma, -5.0 ). Kand $\boldsymbol{L}$ show the relationship of the injection to ChAT-positive and Tph2-positive neurons in this area, respectively. $M, N$, Retrograde labeling of IPDL neurons from the DTg. SP immunoreactivity indicates the input fibers from the dorsal MHb. The IPDL does not contain $\alpha 5^{\mathrm{GFP}}$ neurons. 4V, Fourth ventricle; $7 \mathrm{n}$, facial nerve; $\mathrm{Aq}$, aqueduct; $\mathrm{Cb}$, cerebellum; DR, dorsal raphe; IC, inferior colliculus; IPF, interpeduncular fossa; $\mathrm{LC}$, locus ceruleus; $\mathrm{LDTgV}$, lateral dorsal tegmental nucleus, ventral; $\mathrm{mcp}$, middle cerebellar peduncle; mIf, medial longitudinal fasciculus; $\mathrm{MM}$, medial mammillary nucleus; M05, motor trigeminal nucleus; PAG, periaqueductal gray; Pn, pons; PnC, pontine reticular nucleus, caudal; PnR, pontine raphe nucleus; Pr5, principal trigeminal nucleus; Pr5DM, principal trigeminal nucleus, dorsomedial; Pr5VL, principal trigeminal nucleus, ventrolateral; py, pyramidal tract; R, red nucleus; RLi, rostral linear nucleus of raphe; 55 , sensory root of $5 \mathrm{n}$; SC, superior colliculus; scp, superior cerebellar peduncle; SNC, substantia nigra, pars compacta; SNR, substantia nigra, pars reticulata; SO, supraoptic nucleus; vtgx, ventral tegmental decussation; xscp, decussation superior cerebellar peduncle ventral part. Scale bars: $\boldsymbol{B}, \boldsymbol{E}, \boldsymbol{J}, 400 \mu \mathrm{m} ; \boldsymbol{C}, \boldsymbol{F}, 200 \mu \mathrm{m} ; \boldsymbol{D}, \mathbf{G}, \boldsymbol{K}-\boldsymbol{N}, 100 \mu \mathrm{m} ; \boldsymbol{H}, \mathbf{I}, 25 \mu \mathrm{m}$. 

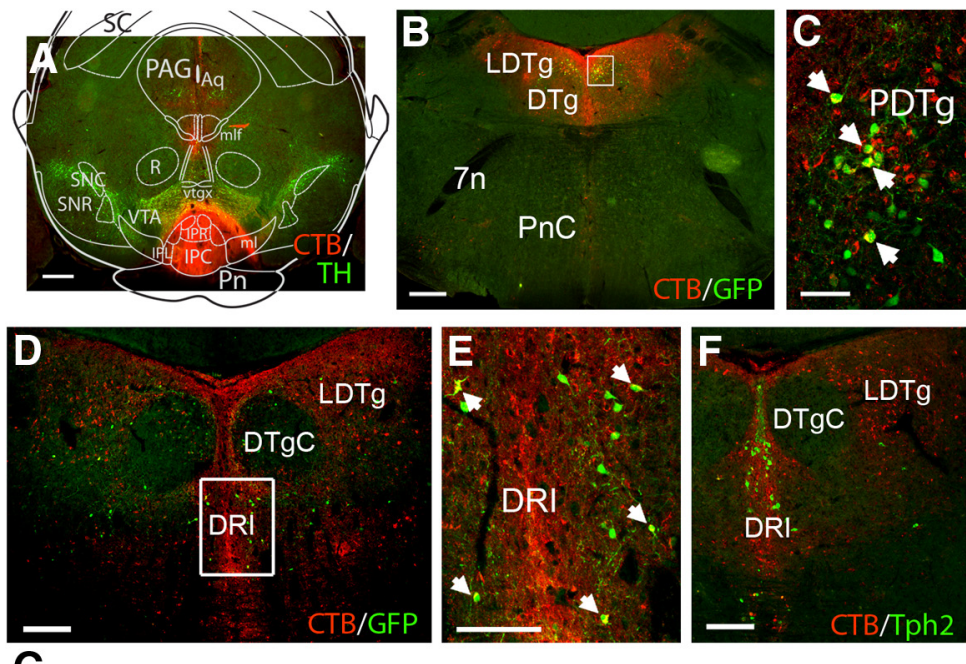

$\mathbf{G}$

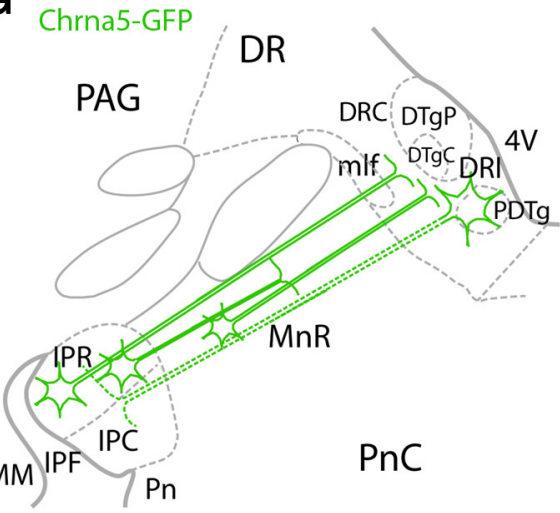

Figure 7. Hindbrain $\alpha 5^{\mathrm{GFP}}$ neurons project to the interpeduncular nucleus. Stereotaxic injections of CTB into the IP of adult $\alpha 5^{\text {GFP }}$ mice were used to retrogradely trace IP afferents. $\boldsymbol{A}$, Injection site of CTB in the IP, encompassing IPR, IPC, and IPL on the right side. $\boldsymbol{B}, \boldsymbol{C}$, Section through the caudal DTg at the level of the facial nerve (7n). Retrograde labeling of $\alpha 5^{\mathrm{GFP}}$ neurons in the PDTg is indicated by arrows. Neurons in this area were also retrogradely labeled by injections in the MnR (data not shown). $\boldsymbol{D}-\boldsymbol{F}$, More rostral section through the DTg. The $\alpha 5^{\mathrm{GFP}}$ neurons adjacent to DRI are retrogradely labeled from the IP (E, arrows). The location of these neurons may be equivalent to the PMnR at more rostral levels. $\boldsymbol{F}$, Location of 5 -HT neurons in an adjacent section. $\mathbf{G}$, Schematic of the projections of $\alpha 5^{\text {GFP }}$ neurons associated with the IP and raphe, shown in the sagittal view. Abbreviations appear in Figure 6 legend. Scale bars: $\boldsymbol{A}, \boldsymbol{B}, 400 \mu \mathrm{m} ; \boldsymbol{D}, \boldsymbol{F}, 200 \mu \mathrm{m} ; \boldsymbol{E}, 100 \mu \mathrm{m} ; \boldsymbol{C}, 50 \mu \mathrm{m}$.

$\alpha 4$ (or $\alpha 2) \beta 2$ (Grady et al., 2009). Autoradiographic binding studies of nicotinic receptor knock-out mice show $\beta 4$-containing receptors are required for much but not all of IP nicotinic ligand binding (Baddick and Marks, 2011). However, ligand binding in the IP may be contributed by either the presynaptic vMHb fiber terminals or the postsynaptic IP neurons, and these cannot be resolved by ligand-binding studies in homogenates or autoradiography. Instead, to determine the likely subunits associated with $\alpha 5^{\mathrm{GFP}}$ in the IP, we took an electrophysiological approach, using pulsed application of nicotine combined with specific inhibitors of nAChR subtypes. First, however, we considered whether the use of the $\alpha 5^{\mathrm{GFP}} \mathrm{BAC}$ transgene might lead to the mis-expression of $\alpha 3$ and $\beta 4 \mathrm{nAChR}$ subunits, because of the genomic clustering of the Chrna3, Chrnb4, and Chrna5 genes that are all encompassed within the parent BAC. Because $\alpha 3$ and $\beta 4$ are cotranscribed on the same strand, we chose to examine $\beta 4$ mRNA expression by in situ hybridization in the $\mathrm{MHb}$ and IP. The $\beta 4$ expression appeared to be increased in the vMHb of $\alpha 5^{\mathrm{GFP}}$ mice relative to controls (Fig. $9 \mathrm{~A}, \mathrm{~B}$ ) but was unchanged in the IP, where only a faint signal could be detected (Fig. 9C,D). This demonstrates that the fidelity of tissuespecific gene expression from this BAC transgene is maintained for the transgenic copies(s) of the Chrnb4 gene and that use of the $\alpha 5^{\text {GFP }}$

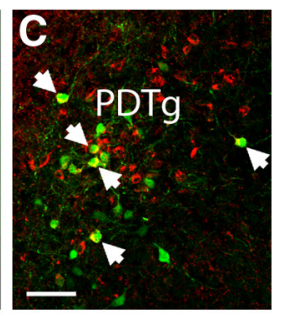

BAC transgene as a marker to identify specific IP neurons is unlikely to affect the nAChR subunit composition of those neurons.

To assess the contribution of specific nAChR complexes to nicotine responses in the vMHb and in $\alpha 5^{\mathrm{GFP}}$ neurons in the IP, we examined nicotine-evoked currents in the presence of $\mathrm{DH} \beta \mathrm{E}$, a partially selective inhibitor of $\alpha 4 \beta 2$-containing receptors, and SR16584 (Zaveri et al., 2010), a specific inhibitor of $\alpha 3 \beta 4$-containing receptors, in the presence of glutamate receptor blockers. To minimize nAChR desensitization known to occur with prolonged nicotine exposure (Covernton and Lester, 2002), responses were evoked by brief pulsed applications of nicotine every 3 min ( $90 \mathrm{~ms}$ pulse, $0.5 \mathrm{~mm}$ nicotine; Fig. $9 E-$ $L)$. Pulsed application of nicotine evoked much stronger currents in cholinergic vMHb neurons than in $\alpha 5^{\mathrm{GFP}}$ IP neurons. The peak amplitude of the nicotine currents was $1564 \pm 1225 \mathrm{pA}$ (range, 633-4076 pA; $n=10$ cells) in the vMHb and $297 \pm 211 \mathrm{pA}$ (range, $110-853 \mathrm{pA} ; n=16$ cells) in the IP. The much greater magnitude of evoked currents observed in the vMHb was not surprising given the high levels of $\mathrm{nAChR}$ mRNA known to be expressed there and past studies showing intense $\mathrm{nAChR}$ ligand binding in the $\mathrm{MHb}$ and its efferent fibers (Harris et al., 1996).

In vMHb neurons, the broadly specific nAChR inhibitor mecamylamine abolished nearly all of the inward nicotine currents as expected, and this inhibition was partially reversible (Fig. 9E, $G$; control, $1398 \pm 1097 \mathrm{pA}$; mecamylamine, $88 \pm 29$ pA; $p<0.01$, Friedman test and Dunn's multiple comparisons test; $n=4$ cells). SR16584 inhibited a majority of these currents in the vMHb (Fig. $9 F, H$; control, $1674 \pm 1394$ pA; SR16584, $282 \pm 127$ pA; $p<$ 0.05 , Friedman test and Dunn's multiple comparisons test; $n=6$ cells), demonstrating that $\alpha 3 \beta 4$-containing nAChRs account for most of the vMHb nicotine response; this inhibitor was poorly reversible in washout experiments. In $\alpha 5^{\mathrm{GFP}}$ IP neurons, nicotine-induced inward currents were partly inhibited by $\mathrm{DH} \beta \mathrm{E}$ in 6 of 10 of the neurons recorded (Fig. $9 I, K$; control, $259 \pm 158 \mathrm{pA} ; \mathrm{DH} \beta \mathrm{E}, 212 \pm 155 \mathrm{pA} ; p<0.05$, Wilcoxon test $n=$ 10 cells) and by SR 16584 in all neurons recorded (Fig. 9J, L; control, $360 \pm 286 \mathrm{pA}$; SR16584, $84 \pm 69 \mathrm{pA} ; p<0.05$, Wilcoxon test; $n=6$ cells). These data suggest the presence of both $\alpha 4 \beta 2$ and $\alpha 3 \beta 4$-containing nAChRs in the IP, either of which could potentially incorporate $\alpha 5$ subunits.

\section{Discussion}

The cholinergic projection from the MHb to the IP has long been thought to mediate behavioral effects of nicotine, but its exact role has been elusive. Experiments in animal models have shown directly that the habenulopeduncular system plays a role in nicotine withdrawal (Salas et al., 2009). The complements of unusual nAChRs expressed in the MHb and IP are candidates for 


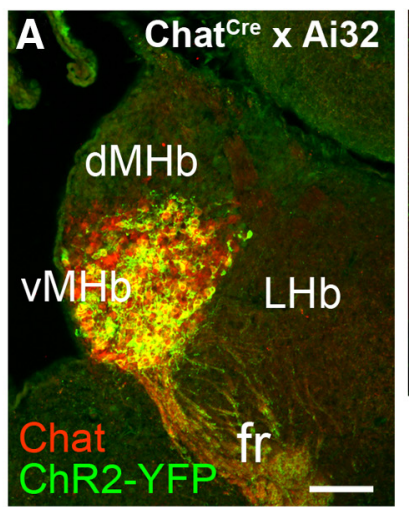

D
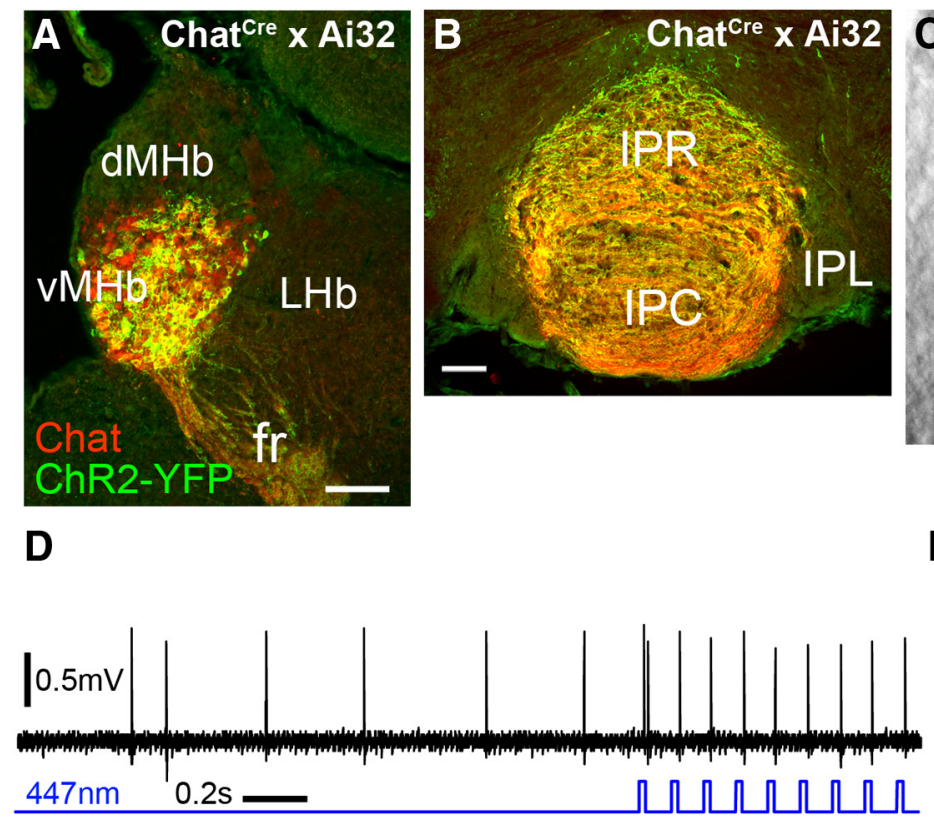

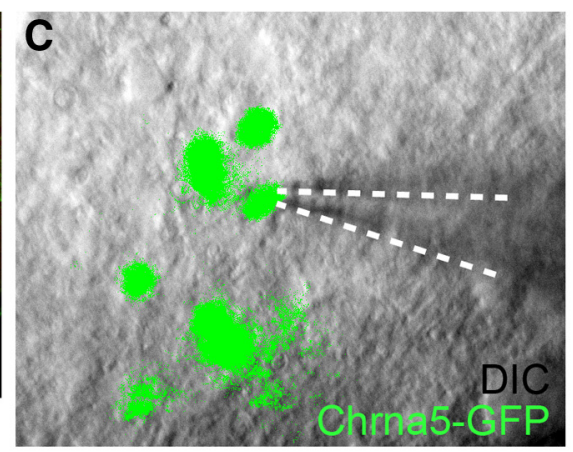

E
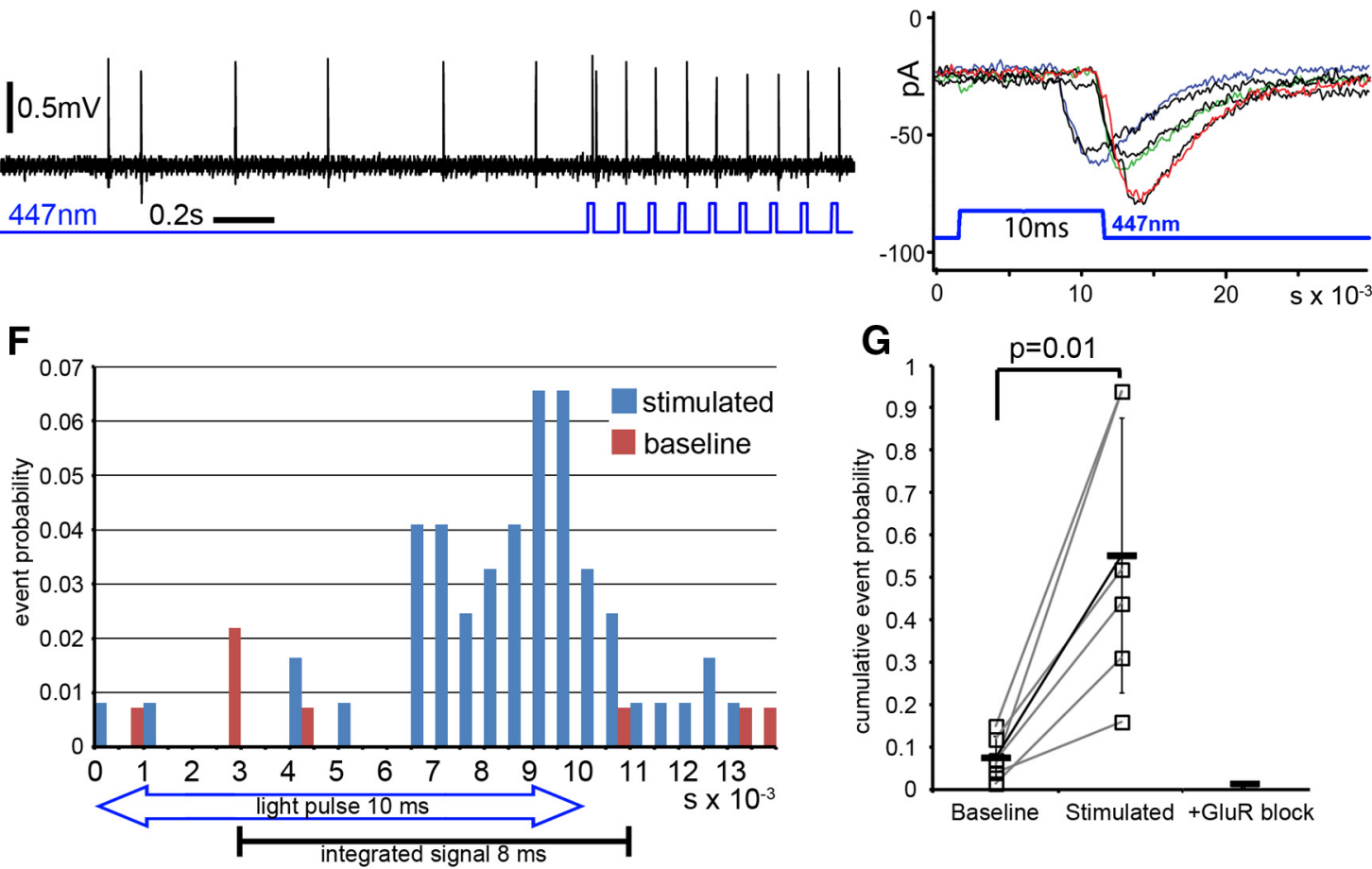

G

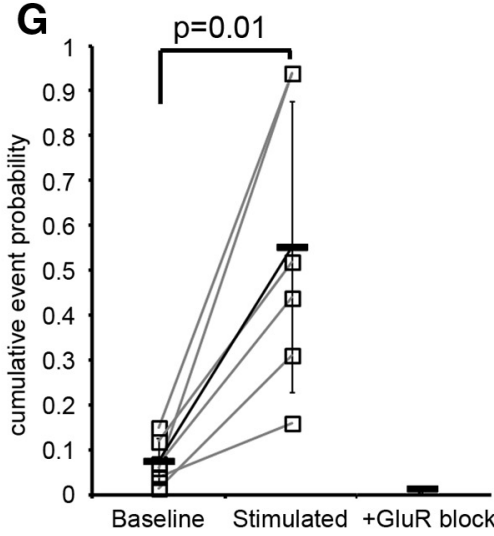

Figure 8. Optogenetically assisted circuit mapping of vMHb inputs to $\alpha 5$-expressing neurons in the IPR. A, Expression of ChR2-EYFP fluorescence and immunofluorescence for ChAT in the MHb of a Chat ${ }^{\text {Cre }}$, Ai32 mouse. Expression of ChR2-EYFP is restricted to the cholinergic vMHb. B, Marker expression in the IP of a Chat ${ }^{\text {Cre }}$, Ai32 mouse. Expression is restricted to the termination zone of the cholinergic MHb fibers in the IPR/IPC, sparing the IPL. C, Image of GFP fluorescence superimposed on a differential interference contrast view of a section through the IPR in a $\alpha 5^{\text {GFP }}$, Chat ${ }^{\text {Cre }}$, Aiz 7 mouse prepared for "visual patch" electrophysiological recording. The shadow of the patch pipette is marked with a dashed line. $\boldsymbol{D}$, Loose-seal, cell-attached current-clamp recording of a vMHb neuron from a Chat ${ }^{\text {Cre }} \times$ Ai32 mouse (as in A). At baseline, irregular tonic firing at $\sim 3 \mathrm{~Hz}$ is observed. Application of $447 \mathrm{~nm}$ blue light pulses $\left(20 \mathrm{~ms}, 2.0 \mathrm{~mW} / \mathrm{mm}^{2}\right)$ at $10 \mathrm{~Hz}$ elicits action potentials entrained to the pulse frequency. The maximum stimulation rate for which the cell shown would generate 1:1 action potentials was $\sim 10 \mathrm{~Hz}$; at higher stimulation frequencies, some light pulses failed to elicit spikes. At the end of a 10 s interval of pulsed light delivery, a period of suppressed firing was observed ( $~ 3 s$, not shown), followed by a gradual resumption of firing at the baseline rate. E, Examples of EPSCs from a single $\alpha 5^{\mathrm{GFP}}$ IP neuron from a $\alpha 5^{\mathrm{GFP}}$, Chat ${ }^{\text {Cre }}$, Ai27 mouse evoked by a $10 \mathrm{~ms}$ light pulse. EPSCs from 6 of 122 sweeps are shown (56 of 122 sweeps elicited EPSCs in this cell). EPSCs from this cell showed multiple consistent latencies relative to light onset and multiple amplitudes, suggesting input from more than one light-responsive presynaptic unit. $\boldsymbol{F}$, Histogram of the latencies of all light-evoked EPSCs from the neuron shown in $\boldsymbol{E}$. Bars depict the probability of observing the onset of an EPSC (event) within an $0.5 \mathrm{~ms}$ epoch at the specified times after light onset (latency). Light onset is at time 0; EPSCs were thresholded as described in Materials and Methods. The latencies for this cell are bimodally distributed, with peaks at 6.5-7 ms and 9-9.5 ms, suggesting inputs from two different presynaptic units. Other cells showed a single peak. G, Probability of light-evoked EPSCs in $\alpha 5^{\text {GFP }}$ neurons summed over the 3-11 ms period after a light pulse (stimulated, $n=6$ ), after a "sweep" without a light pulse (baseline, $n=6$ ), and after a light pulse in the presence of glutamatergic blockers $(n=4)$. The probability of evoking a light-stimulated EPSC for the cells shown ranged from 0.16 to 0.94 . Inhibition of EPSCs by blockade of glutamatergic signaling also demonstrates that the recorded $\alpha 5^{\text {GFP }}$ cells were not intrinsically photostimulated. $p=0.01$ (paired t test; $n=6$ cells). Results are presented as means (SD). dMHb, medial habenula, dorsal part; fr, fasciculus retroflexus; LHb, lateral habenula. Scale bars: $A, B, 100 \mu \mathrm{m}$.

mediating this and other nicotine effects. This, combined with the possibility of a genetic link between haplotypes at the CHRNa5/a3/b4 locus and smoking, has led to great interest in the functional roles of these receptors (Improgo et al., 2010; Berrettini and Doyle, 2012; Leslie et al., 2013).

Here we first used quantitative methods to clarify the expression of $\alpha 5$ mRNA in the mouse MHb. Our nonisotopic in situ hybridization methods could not detect $\alpha 5$ mRNA in the habe- nula, despite a very strong IP signal. However, two prior ${ }^{35} \mathrm{~S}$ in situ hybridization studies in the mouse have detected weak $\alpha 5$ signals using conspecific probes from the diverged third intracytoplasmic loop of the receptor (Franceschini et al., 2002; Salas et al., 2003), which are likely to be specific, and these agree with similar studies using rat probes (Marks et al., 1992; Heath et al., 2010). All of these studies reported $\alpha 5$ mRNA expression barely above the threshold of detection in the MHb and reported $\alpha 5$ 

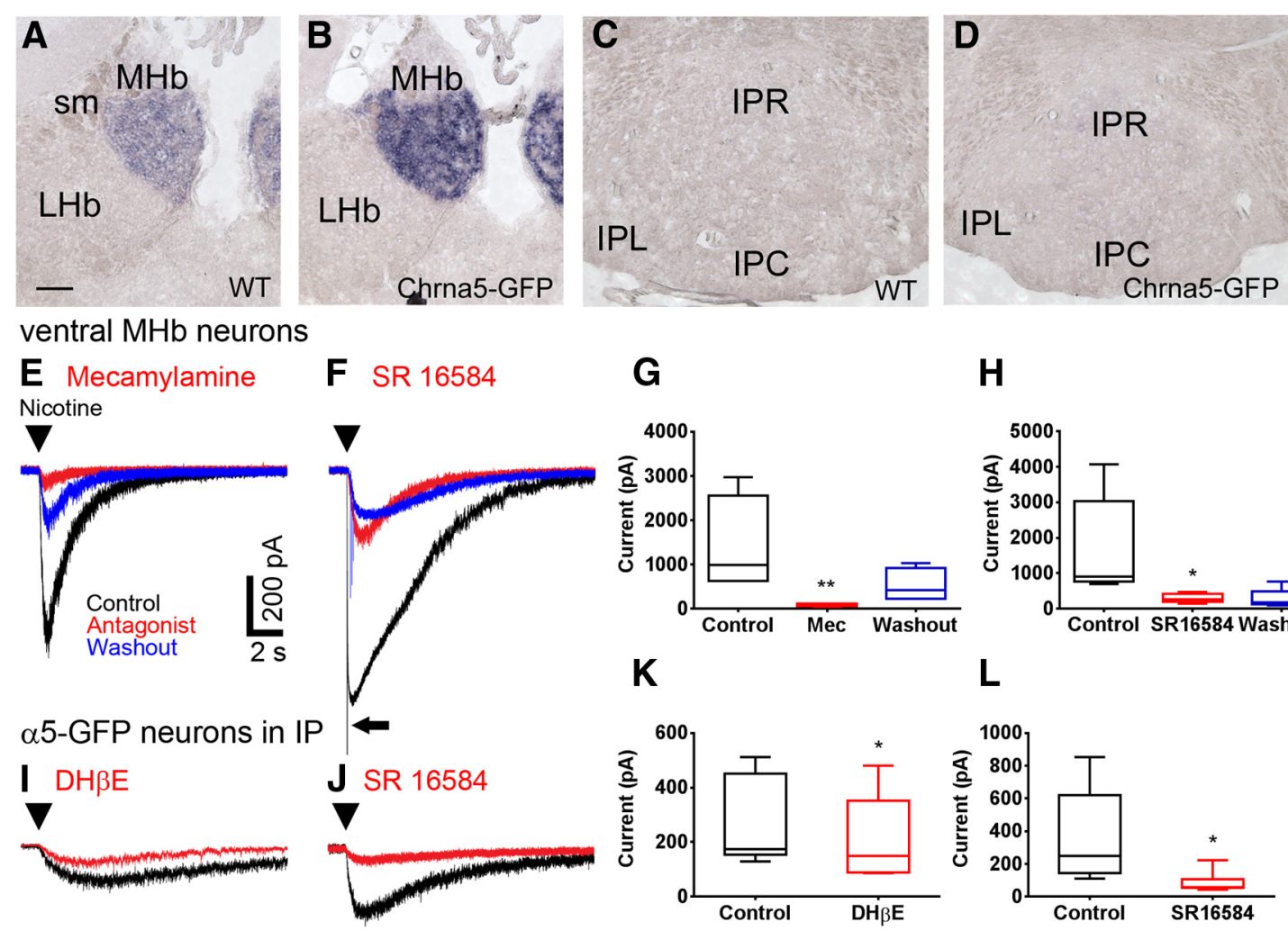

H

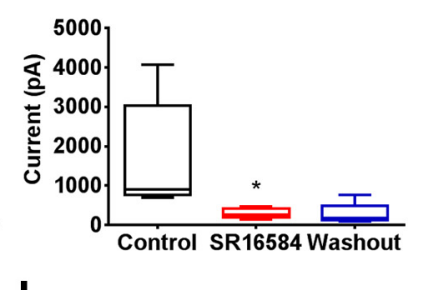

\section{L}

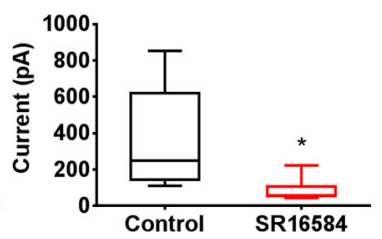

Figure 9. Nicotinic pharmacology of $\alpha 5^{+}$IPR neurons. A-D, Chrnb4 mRNA expression in the habenulopeduncular system of control and $\alpha 5^{\text {GFP }}$ mice. The $\alpha 5^{\text {GFP }}$ BAC drives overexpression of

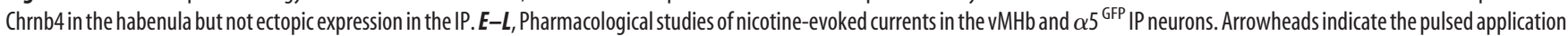
of $0.5 \mu \mathrm{m}$ nicotine for $90 \mathrm{~ms}$. Black traces, Control or baseline responses to nicotine; red traces, nicotine current responses in the presence of the stated inhibitor in bath; blue traces, nicotine current responses during recovery after washout. $\boldsymbol{E}, \boldsymbol{F}$, Nicotine-evoked currents in the $\mathrm{vMHb}$ are nearly abolished by mecamylamine (Mec; $5 \mu \mathrm{M}$ ) and markedly inhibited by SR16584 (20 $\mu \mathrm{m})$, a selective inhibitor of $\alpha 3 \beta 4$-containing receptors. The arrow in $\boldsymbol{F}$ indicates an action potential evoked immediately after nicotine application but beyond effective space clamp. $\boldsymbol{G}, \boldsymbol{H}$, Summary of inhibitor effects on nicotine-evoked currents in vMHb neurons. $\mathbf{G}$, Effect of mecamylamine, which was partially reversible. ${ }^{* *} p<0.01$ compared with control (Friedman test and Dunn's multiple comparisons

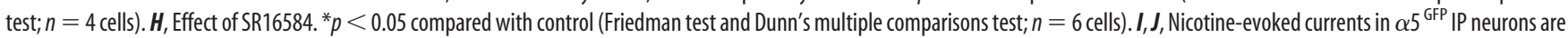
inhibited by $\mathrm{DH} \beta \mathrm{E}(2 \mu \mathrm{M})$, a partially selective inhibitor of $\alpha 4 \beta 2$ receptors, and by SR16584. $\boldsymbol{K}, \boldsymbol{L}$, Summary of inhibitor effects on nicotine-evoked currents in the IP. $\boldsymbol{K}$, Effects of DH $\beta$ E. ${ }^{*} p<0.05$ (Wilcoxon test; $n=10$ cells). Only 6 of 10 cells appeared to respond to this inhibitor. L, Effects of SR16584. ${ }^{*} p<0.05$ (Wilcoxon test; $n=6$ cells). All recordings were obtained in the presence of DNQX (10 $\mu \mathrm{M})$ and D-AP-5 $(50 \mu \mathrm{M})$ to block glutamatergic signaling. In the "box and whisker" graphs in $\mathbf{G}, \boldsymbol{H}, \boldsymbol{K}$, and $\boldsymbol{L}$, the box extends from the 25 th to 75 th percentile, the median is designated by the line in the middle of the box, and the whiskers indicated the smallest and largest values. Abbreviations appear in Figure 4 legend. Scale bars: A-D, $100 \mu \mathrm{m}$.

expression incidental to other findings. The sensitivity of the ${ }^{35} \mathrm{~S}$ autoradiographic methods used in these reports is probably higher than the nonisotopic methods used here, or in the Allen Mouse Brain Atlas, leading to detection of this weak signal. Thus, these studies are consistent with our quantitative analysis showing very low levels of $\alpha 5 \mathrm{mRNA}$ in the MHb. We conclude that $\alpha 5$ mRNA expression in the $\mathrm{MHb}$ is much lower than that of the other $\mathrm{nAChR}$ subunits expressed there and much lower than in other brain regions where it has been detected. Indeed, in the $\mathrm{MHb}$ the Chrna5/a3/b4 gene locus is transcribed with remarkable specificity for the strand that encodes the $\alpha 3$ and $\beta 4$ receptors.

The expression of functional nAChR complexes in the habenulopeduncular system has also been characterized by radioligand binding using autoradiography in tissue sections and by immunoprecipitation of membrane preparations from brain homogenates, most frequently using ${ }^{3} \mathrm{H}$ - and ${ }^{125} \mathrm{I}$-epibatidine, respectively. Although epibatidine binds all nAChR subtypes with high affinity, relatively specific competitors (autoradiography) or precipitation of complexes with specific antibodies (homogenates) can be used to identify receptor subunit composition. ${ }^{3} \mathrm{H}-$ epibatidine autoradiography has been used to examine Chrna5 null mutant mice, but because $\alpha 5$ does not participate in ligand binding, loss of $\alpha 5$ does not affect these results. In contrast, loss of the $\beta 4$ subunit has a profound effect on $\mathrm{MHb}$ binding of ${ }^{3} \mathrm{H}-$ epibatidine (Baddick and Marks, 2011), consistent with our results showing marked inhibition of nicotine-evoked currents with the $\alpha 3 \beta 4$ inhibitor SR16584.

Immunoprecipitation of ${ }^{125}$ I-epibatidine-labeled receptors in brain homogenates has the limitation that both presynaptic and postsynaptic membranes are included in the preparation. Thus, in the IP, the contribution of afferent MHb fibers and expression in local IP neurons to overall binding cannot be distinguished. Immunoprecipitation studies have shown variable results for the $\alpha 5$ receptor in the habenula. In one study, moderate levels of $\alpha 5$ receptor-containing complexes were detected in the rat habenula and low levels in the mouse (Grady et al., 2009). However, in this study, the $\alpha 5$ immunoprecipitation signal from the rat habenula was nearly eliminated by immunodepletion of the preparation with $\beta 2$ receptor antibodies. This suggests that the $\alpha 5$-containing receptors in this preparation did not originate in the MHb because autoradiographic studies of the $\mathrm{MHb}$ indicate that loss of the $\beta 2$ receptor has a minimal effect on ${ }^{3} \mathrm{H}$-epibatidine binding in the MHb (Baddick and Marks, 2011) and that binding there is primarily dependent on the $\beta 4$ receptor. A possible source for receptors containing the $\alpha 5$ and $\beta 2$ subunits in habenula samples is the large projection from layer 5-6 cortical neurons that terminates in the dorsal thalamus, immediately ventral to the habenula. The association of $\alpha 5$ and $\beta 2$ subunits in functional 
receptors from this region has been shown (Heath et al., 2010). A more recent immunoprecipitation study showed very low levels of $\alpha 5$-containing receptor complexes in the habenula ( $\mathrm{MHb}$ plus $\mathrm{LHb}$ ) of postnatal day 18 rat and mouse (6\% of $3 \mathrm{H}$-epibatidinebinding receptors in mice and $2.5 \%$ in rats; Scholze et al., 2012), consistent with our quantitative mRNA expression data.

We conclude that it is not likely that the $\alpha 5$ subunit forms stoichiometric complexes with the abundant $\alpha 3 \beta 4 \mathrm{nAChRs}$ in the MHb. Although it has been established in multiple laboratories that loss of the $\alpha 5$ receptor results in nicotine-related behavioral changes (Salas et al., 2003, 2009; Gangitano et al., 2009; Fowler et al., 2011), these effects probably do not result from the loss of $\alpha 5$ function in the $\mathrm{MHb}$. We also conclude that the behavioral effects reported after the use of viral vectors to drive $\alpha 5$ expression in the MHb of $\alpha 5$ knock-out mice (Fowler et al., 2011) or of $\beta 4$-overexpressing mice (Frahm et al., 2011) are likely to result from the nonphysiological expression of this subunit, not a "rescue" of normal function. Instead, in the habenulopeduncular pathway, $\alpha 5$-expressing IP neurons are more likely to mediate the effects of the $\alpha 5$ knock-out. Also, expression studies showing $\alpha 5$ mRNA in the VTA/SN (Azam et al., 2002) and $\alpha 5$ receptors on DA terminals in the striatum (Zoli et al., 2002), combined with recent work showing alterations in evoked DA release in the dorsal striatum of $\alpha 5$ knock-out mice (Exley et al., 2012), suggest that some $\alpha 5$ behavioral effects may be mediated by the nigrostriatal pathway. Ultimately, the definitive site of action of the $\alpha 5$ subunit in behavioral responses to nicotine may only be resolved by the conditional deletion of Chrna5 in specific brain regions.

As an "accessory" subunit, $\alpha 5$ lacks intrinsic channel-forming or ligand-binding ability. Thus, the identity of the available channel-forming $\alpha$ - and $\beta$-subunit partners for the formation of functional pentameric receptors is essential to $\alpha 5$ function. Here we have shown that specific inhibitors of both $\alpha 3 \beta 4$ - and $\alpha 4 \beta 2$ containing receptors reduce nicotine-induced currents in $\alpha 5^{\mathrm{GFP}}$ IP neurons. Significant inhibition by the $\alpha 3 \beta 4$ antagonist SR16584 is somewhat surprising given the very low levels of $\beta 4$ mRNA detected in the IP (Fig. 4). However, in these experiments, high concentrations of nicotine were applied $(0.5 \mu \mathrm{M})$ to intentionally maximize activity of the relatively low-affinity $\alpha 3 \beta 4$ receptors. Furthermore, the absolute magnitude of the SR16584inhibitable current is much greater in the vMHb than in $\alpha 5^{\mathrm{GFP}}$ IP neurons, consistent with the higher expression of $\alpha 3$ and $\beta 4$ mRNA in the vMHb. Finally, we cannot rule out inhibitory activity of SR16584 on receptor complexes other than $\alpha 4 \beta 2$ and $\alpha 3 \beta 4$, on which it has not been tested (Zaveri et al., 2010). The inhibitor data presented here are otherwise consistent with prior in situ hybridization data that show expression of the widely distributed $\alpha 4$ and $\beta 2$ receptors in the IP, and also the more restricted $\alpha 2$ and $\alpha 3$ subunits (Wada et al., 1989; Marks et al., 1992). In ${ }^{3} \mathrm{H}$-epibatidine-binding studies, competition of binding with specific inhibitors (Perry et al., 2002; Baddick and Marks, 2011), combined with knock-out studies (Baddick and Marks, 2011), also suggests that the IP contains predominantly presynaptic $\alpha 3 \beta 4$ receptors expressed on afferent MHb fibers and $\alpha 4 \beta 2$ receptors expressed on postsynaptic IP neurons. The relevance of the probable IP $\alpha 4 \beta 2 \alpha 5$-containing receptor complexes to nicotine-related behaviors is supported by the observation that the smoking-associated human $\alpha 5$ variant, D398N, increases receptor desensitization when incorporated into $(\alpha 4 \beta 2)_{2} \alpha 5$ receptor complexes, but not into $(\alpha 3 \beta 4)_{2} \alpha 5$ or $(\alpha 3 \beta 2)_{2} \alpha 5$ complexes (Kuryatov et al., 2011).

The expression of the $\alpha 5$ receptor on GABAergic interneurons in the IP and MnR suggests a possible role for $\alpha 5$-expressing neurons in modulating some of the behavioral effects of nicotine. These effects may extend beyond the known role of the $\alpha 5$ receptor in mediating the aversion to high doses of nicotine that is lost in the $\alpha 5$ null mouse. A major reason cited by smokers for nicotine use is the anxiolytic effect of nicotine, or "stress relief" (Bruijnzeel, 2012). However, in rodents, nicotine can have either anxiolytic or anxiogenic effects, depending on the dose, timing of administration, and behavioral model used (Picciotto et al., 2002; Morissette et al., 2007). It is likely that these variable effects are attributable to the distribution of nAChRs in many brain regions and the ability of nicotine to cause both activation and desensitization of these receptors. Here we have shown that the expression of the $\alpha 5$ subunit characterizes a distinctive population of GABAergic neurons in the IP and raphe whose axonal projections and cell bodies, respectively, have a close relationship to the ventral and caudal parts of the midbrain 5-HT system, particularly the MnR, DRC, and DRI. Neurons in these regions are particularly activated in rodent models of stress (Hale et al., 2012; Spiacci et al., 2012) and in nicotine withdrawal (Sperling and Commons, 2011). Thus, brainstem $\alpha 5$ expressing GABAergic neurons are strong candidates for mediating the anxiolytic effects of nicotine via inhibition of 5-HT neurons in these areas.

\section{References}

Allen Institute for Brain Science (2012) Allen mouse brain atlas. E-book available at http://mouse.brain-map.org/.

Azam L, Winzer-Serhan UH, Chen Y, Leslie FM (2002) Expression of neuronal nicotinic acetylcholine receptor subunit mRNAs within midbrain dopamine neurons. J Comp Neurol 444:260-274. CrossRef Medline

Baddick CG, Marks MJ (2011) An autoradiographic survey of mouse brain nicotinic acetylcholine receptors defined by null mutants. Biochem Pharmacol 82:828-841. CrossRef Medline

Berrettini WH, Doyle GA (2012) The CHRNA5-A3-B4 gene cluster in nicotine addiction. Mol Psychiatry 17:856-866. CrossRef Medline

Boulter J, O’Shea-Greenfield A, Duvoisin RM, Connolly JG, Wada E, Jensen A, Gardner PD, Ballivet M, Deneris ES, McKinnon D (1990) Alpha 3, alpha 5, and beta 4: three members of the rat neuronal nicotinic acetylcholine receptor-related gene family form a gene cluster. J Biol Chem 265:4472-4482. Medline

Bruijnzeel AW (2012) Tobacco addiction and the dysregulation of brain stress systems. Neurosci Biobehav Rev 36:1418-1441. CrossRef Medline

Covernton PO, Lester RA (2002) Prolonged stimulation of presynaptic nicotinic acetylcholine receptors in the rat interpeduncular nucleus has differential effects on transmitter release. Int J Dev Neurosci 20:247-258. CrossRef Medline

Eckenrode TC, Barr GA, Battisti WP, Murray M (1987) Acetylcholine in the interpeduncular nucleus of the rat: normal distribution and effects of deafferentation. Brain Res 418:273-286. CrossRef Medline

Exley R, McIntosh JM, Marks MJ, Maskos U, Cragg SJ (2012) Striatal alpha5 nicotinic receptor subunit regulates dopamine transmission in dorsal striatum. J Neurosci 32:2352-2356. CrossRef Medline

Fedtsova NG, Turner EE (1995) Brn-3.0 Expression identifies early postmitotic CNS neurons and sensory neural precursors. Mech Dev 53:291304. CrossRef Medline

Fowler CD, Lu Q, Johnson PM, Marks MJ, Kenny PJ (2011) Habenular alpha5 nicotinic receptor subunit signalling controls nicotine intake. Nature 471:597-601. CrossRef Medline

Frahm S, Slimak MA, Ferrarese L, Santos-Torres J, Antolin-Fontes B, Auer S, Filkin S, Pons S, Fontaine JF, Tsetlin V, Maskos U, Ibañez-Tallon I (2011) Aversion to nicotine is regulated by the balanced activity of beta4 and alpha5 nicotinic receptor subunits in the medial habenula. Neuron 70 : 522-535. CrossRef Medline

Franceschini D, Paylor R, Broide R, Salas R, Bassetto L, Gotti C, De Biasi M (2002) Absence of alpha7-containing neuronal nicotinic acetylcholine receptors does not prevent nicotine-induced seizures. Brain Res $\mathrm{Mol}$ Brain Res 98:29-40. CrossRef Medline

Gangitano D, Salas R, Teng Y, Perez E, De Biasi M (2009) Progesterone modulation of alpha $5 \mathrm{nAChR}$ subunits influences anxiety-related behavior during estrus cycle. Genes Brain Behav 8:398-406. CrossRef Medline 
Grady SR, Moretti M, Zoli M, Marks MJ, Zanardi A, Pucci L, Clementi F, Gotti C (2009) Rodent habenulo-interpeduncular pathway expresses a large variety of uncommon nAChR subtypes, but only the alpha3beta $4^{*}$ and alpha3beta3beta $4^{\star}$ subtypes mediate acetylcholine release. J Neurosci 29:2272-2282. CrossRef Medline

Hale MW, Shekhar A, Lowry CA (2012) Stress-related serotonergic systems: implications for symptomatology of anxiety and affective disorders. Cell Mol Neurobiol 32:695-708. CrossRef Medline

Hall W, Madden P, Lynskey M (2002) The genetics of tobacco use: methods, findings and policy implications. Tob Control 11:119-124. CrossRef Medline

Harris J, Källén B, Robert E (1996) The epidemiology of anotia and microtia. J Med Genet 33:809-813. CrossRef Medline

Harris JA, Wook Oh S, Zeng H (2012) Adeno-associated viral vectors for anterograde axonal tracing with fluorescent proteins in nontransgenic and cre driver mice. Curr Protoc Neurosci 59:1.20.1-1.20.18. CrossRef Medline

Heath CJ, King SL, Gotti C, Marks MJ, Picciotto MR (2010) Cortico-thalamic connectivity is vulnerable to nicotine exposure during early postnatal development through alpha4/beta2/alpha5 nicotinic acetylcholine receptors. Neuropsychopharmacology 35:2324-2338. CrossRef Medline

Improgo MR, Scofield MD, Tapper AR, Gardner PD (2010) The nicotinic acetylcholine receptor CHRNA5/A3/B4 gene cluster: dual role in nicotine addiction and lung cancer. Prog Neurobiol 92:212-226. CrossRef Medline

Kim U, Chang SY (2005) Dendritic morphology, local circuitry, and intrinsic electrophysiology of neurons in the rat medial and lateral habenular nuclei of the epithalamus. J Comp Neurol 483:236-250. CrossRef Medline

Kuryatov A, Berrettini W, Lindstrom J (2011) Acetylcholine receptor (AChR) alpha5 subunit variant associated with risk for nicotine dependence and lung cancer reduces (alpha4beta2)(2)alpha5 AChR function. Mol Pharmacol 79:119-125. CrossRef Medline

Leslie FM, Mojica CY, Reynaga DD (2013) Nicotinic receptors in addiction pathways. Mol Pharmacol 83:753-758. CrossRef Medline

Lindstrom J, Anand R, Gerzanich V, Peng X, Wang F, Wells G (1996) Structure and function of neuronal nicotinic acetylcholine receptors. Prog Brain Res 109:125-137. CrossRef Medline

Livak KJ, Schmittgen TD (2001) Analysis of relative gene expression data using real-time quantitative PCR and the 2(-Delta Delta C(T)) method. Methods 25:402-408. CrossRef Medline

Luppi PH, Fort P, Jouvet M (1990) Iontophoretic application of unconjugated cholera toxin B subunit (CTb) combined with immunohistochemistry of neurochemical substances: a method for transmitter identification of retrogradely labeled neurons. Brain Res 534:209-224. CrossRef Medline

Madisen L, Mao T, Koch H, Zhuo JM, Berenyi A, Fujisawa S, Hsu YW, Garcia AJ 3rd, Gu X, Zanella S, Kidney J, Gu H, Mao Y, Hooks BM, Boyden ES, Buzsáki G, Ramirez JM, Jones AR, Svoboda K, Han X, et al. (2012) A toolbox of Cre-dependent optogenetic transgenic mice for light-induced activation and silencing. Nat Neurosci 15:793-802. CrossRef Medline

Marks MJ, Pauly JR, Gross SD, Deneris ES, Hermans-Borgmeyer I, Heinemann SF, Collins AC (1992) Nicotine binding and nicotinic receptor subunit RNA after chronic nicotine treatment. J Neurosci 12:2765-2784. Medline

Morissette SB, Tull MT, Gulliver SB, Kamholz BW, Zimering RT (2007) Anxiety, anxiety disorders, tobacco use, and nicotine: a critical review of interrelationships. Psychol Bull 133:245-272. CrossRef Medline

Nelson ME, Lindstrom J (1999) Single channel properties of human alpha3 AChRs: impact of beta2, beta4 and alpha5 subunits. J Physiol 516:657678. CrossRef Medline

Paxinos G, Franklin KBJ (2001) The mouse brain in stereotaxic coordinates, Ed 2. San Diego: Academic.

Perry DC, Xiao Y, Nguyen HN, Musachio JL, Dávila-García MI, Kellar KJ (2002) Measuring nicotinic receptors with characteristics of alpha4beta2, alpha3beta2 and alpha3beta4 subtypes in rat tissues by autoradiography. J Neurochem 82:468-481. CrossRef Medline

Picciotto MR, Brunzell DH, Caldarone BJ (2002) Effect of nicotine and nicotinic receptors on anxiety and depression. Neuroreport 13:1097-1106. CrossRef Medline

Picciotto MR, Higley MJ, Mineur YS (2012) Acetylcholine as a neuromodulator: cholinergic signaling shapes nervous system function and behavior. Neuron 76:116-129. CrossRef Medline

Piñol RA, Bateman R, Mendelowitz D (2012) Optogenetic approaches to characterize the long-range synaptic pathways from the hypothalamus to brain stem autonomic nuclei. J Neurosci Methods 210:238-246. CrossRef Medline
Quick MW, Ceballos RM, Kasten M, McIntosh JM, Lester RA (1999) Alpha3beta4 subunit-containing nicotinic receptors dominate function in rat medial habenula neurons. Neuropharmacology 38:769-783. CrossRef Medline

Quina LA, Pak W, Lanier J, Banwait P, Gratwick K, Liu Y, Velasquez T, O'Leary DD, Goulding M, Turner EE (2005) Brn3a-expressing retinal ganglion cells project specifically to thalamocortical and collicular visual pathways. J Neurosci 25:11595-11604. CrossRef Medline

Quina LA, Wang S, Ng L, Turner EE (2009) Brn3a and Nurrl mediate a gene regulatory pathway for habenula development. J Neurosci 29:14309_ 14322. CrossRef Medline

Ramirez-Latorre J, Yu CR, Qu X, Perin F, Karlin A, Role L (1996) Functional contributions of alpha5 subunit to neuronal acetylcholine receptor channels. Nature 380:347-351. CrossRef Medline

Ren J, Qin C, Hu F, Tan J, Qiu L, Zhao S, Feng G, Luo M (2011) Habenula "cholinergic" neurons co-release glutamate and acetylcholine and activate postsynaptic neurons via distinct transmission modes. Neuron 69: 445-452. CrossRef Medline

Rossi J, Balthasar N, Olson D, Scott M, Berglund E, Lee CE, Choi MJ, Lauzon D, Lowell BB, Elmquist JK (2011) Melanocortin-4 receptors expressed by cholinergic neurons regulate energy balance and glucose homeostasis. Cell Metab 13:195-204. CrossRef Medline

Salas R, Orr-Urtreger A, Broide RS, Beaudet A, Paylor R, De Biasi M (2003) The nicotinic acetylcholine receptor subunit alpha 5 mediates short-term effects of nicotine in vivo. Mol Pharmacol 63:1059-1066. CrossRef Medline

Salas R, Sturm R, Boulter J, De Biasi M (2009) Nicotinic receptors in the habenulo-interpeduncular system are necessary for nicotine withdrawal in mice. J Neurosci 29:3014-3018. CrossRef Medline

Scholze P, Koth G, Orr-Urtreger A, Huck S (2012) Subunit composition of alpha5-containing nicotinic receptors in the rodent habenula. J Neurochem 121:551-560. CrossRef Medline

Sperling R, Commons KG (2011) Shifting topographic activation and 5-HT1A receptor-mediated inhibition of dorsal raphe serotonin neurons produced by nicotine exposure and withdrawal. Eur J Neurosci 33:18661875. CrossRef Medline

Spiacci A Jr, Coimbra NC, Zangrossi H Jr (2012) Differential involvement of dorsal raphe subnuclei in the regulation of anxiety- and panic-related defensive behaviors. Neuroscience 227:350-360. CrossRef Medline

Thompson CL, Pathak SD, Jeromin A, Ng LL, MacPherson CR, Mortrud MT, Cusick A, Riley ZL, Sunkin SM, Bernard A, Puchalski RB, Gage FH, Jones AR, Bajic VB, Hawrylycz MJ, Lein ES (2008) Genomic anatomy of the hippocampus. Neuron 60:1010-1021. CrossRef Medline

Wada E, Wada K, Boulter J, Deneris E, Heinemann S, Patrick J, Swanson LW (1989) Distribution of alpha 2, alpha 3, alpha 4, and beta 2 neuronal nicotinic receptor subunit mRNAs in the central nervous system: a hybridization histochemical study in the rat. J Comp Neurol 284:314-335. CrossRef Medline

Wada E, McKinnon D, Heinemann S, Patrick J, Swanson LW (1990) The distribution of mRNA encoded by a new member of the neuronal nicotinic acetylcholine receptor gene family (alpha 5) in the rat central nervous system. Brain Res 526:45-53. CrossRef Medline

Wang F, Gerzanich V, Wells GB, Anand R, Peng X, Keyser K, Lindstrom J (1996) Assembly of human neuronal nicotinic receptor alpha5 subunits with alpha3, beta2, and beta4 subunits. J Biol Chem 271:17656-17665. CrossRef Medline

Winzer-Serhan UH, Leslie FM (2005) Expression of alpha5 nicotinic acetylcholine receptor subunit mRNA during hippocampal and cortical development. J Comp Neurol 481:19-30. CrossRef Medline

World Health Organization (2008) WHO report on the global tobacco epidemic, 2008: The MPOWER package. Geneva: WHO

Xiao C, Nashmi R, McKinney S, Cai H, McIntosh JM, Lester HA (2009) Chronic nicotine selectively enhances alpha4beta $2^{\star}$ nicotinic acetylcholine receptors in the nigrostriatal dopamine pathway. J Neurosci 29: 12428-12439. CrossRef Medline

Xu X, Callaway EM (2009) Laminar specificity of functional input to distinct types of inhibitory cortical neurons. J Neurosci 29:70-85. CrossRef Medline

Zaveri N, Jiang F, Olsen C, Polgar W, Toll L (2010) Novel alpha3beta4 nicotinic acetylcholine receptor-selective ligands. Discovery, structure-activity studies, and pharmacological evaluation. J Med Chem 53:8187-8191. CrossRef Medline

Zoli M, Moretti M, Zanardi A, McIntosh JM, Clementi F, Gotti C (2002) Identification of the nicotinic receptor subtypes expressed on dopaminergic terminals in the rat striatum. J Neurosci 22:8785-8789. Medline 